\title{
Upgrading in global value chains
}

\author{
Working Paper No. 28
}

John Humphrey

Policy Integration Department

World Commission on the Social Dimension of Globalization

International Labour Office

Geneva

May 2004 


\section{Copyright (C) International Labour Organization 2004}

Publications of the International Labour Office enjoy copyright under Protocol 2 of the Universal Copyright Convention. Nevertheless, short excerpts from them may be reproduced without authorization, on condition that the source is indicated. For rights of reproduction or translation, application should be made to the Publications Bureau (Rights and Permissions), International Labour Office, CH-1211 Geneva 22, Switzerland. The International Labour Office welcomes such applications.

Libraries, institutions and other users registered in the United Kingdom with the Copyright Licensing Agency, 90 Tottenham Court Road, London W1T 4LP [Fax: (+44) (0)20 7631 5500; email: cla@cla.co.uk], in the United States with the Copyright Clearance Center, 222 Rosewood Drive, Danvers, MA 01923 [Fax: (+1) (978) 750 4470; email: info@copyright.com] or in other countries with associated Reproduction Rights Organizations, may make photocopies in accordance with the licences issued to them for this purpose.

ISBN 92-2-116015-7 (printed version)

ISBN 92-2-116016-5 (web version)

First published 2004

Cover:

The designations employed in ILO publications, which are in conformity with United Nations practice, and the presentation of material therein do not imply the expression of any opinion whatsoever on the part of the International Labour Office concerning the legal status of any country, area or territory or of its authorities, or concerning the delimitation of its frontiers.

The responsibility for opinions expressed in signed articles, studies and other contributions rests solely with their authors, and publication does not constitute an endorsement by the International Labour Office of the opinions expressed in them.

Reference to names of firms and commercial products and processes does not imply their endorsement by the International Labour Office, and any failure to mention a particular firm, commercial product or process is not a sign of disapproval.

ILO publications can be obtained through major booksellers or ILO local offices in many countries, or direct from ILO Publications, International Labour Office, CH-1211 Geneva 22, Switzerland. Catalogues or lists of new publications are available free of charge from the above address, or by email: pubvente@ilo.org

Visit our website: $\underline{w w w . i l o . o r g / p u b l n s}$

Printed by the International Labour Office, Geneva, Switzerland 


\section{Upgrading in global value chains}

\section{Contents}

Foreword

Preface

1. Introduction .1

2. New forms of coordinating global production and distribution 3

3. Upgrading.

4. Global buyers, access to global markets and upgrading ...............................................................12

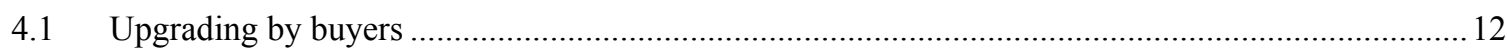

4.2 Limits and vulnerabilities of buyer-promoted upgrading ........................................................ 15

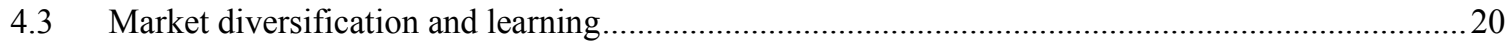

4.4 Building on buyer linkages: Upgrading in Taiwan, China ...................................................21

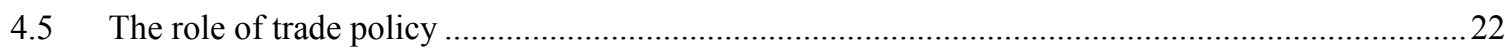

5. Upgrading within chains: Making the chain more sophisticated ............................................................23

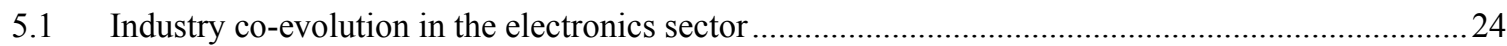

5.2 "Growing up with the sector": The acquisition of capabilities by suppliers in the African

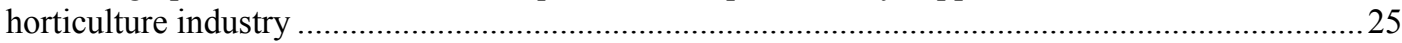

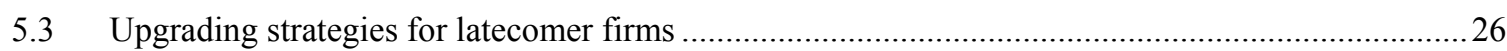

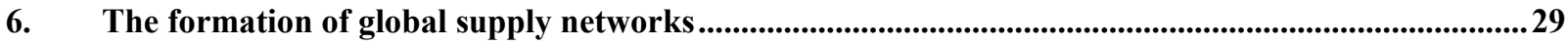

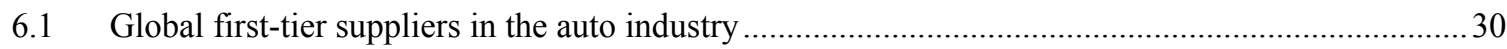

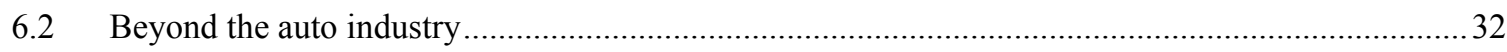

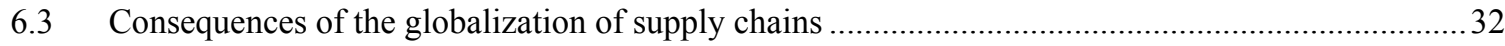

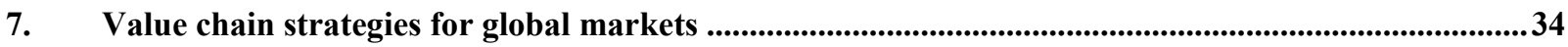

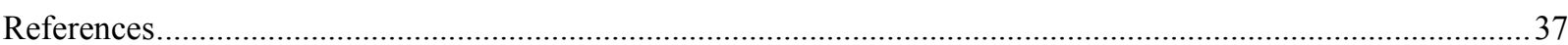





\title{
Foreword
}

In February 2002, the ILO established an independent World Commission on the Social Dimension of Globalization, co-chaired by President Tarja Halonen of Finland and President Benjamin Mkapa of Tanzania and comprising 26 eminent commissioners from a wide range of walks of life and different parts of the world, each serving in their individual capacity. Its broad goals were: to identify policies for globalization that reduce poverty, foster growth and development in open economies, and widen opportunities for decent work; to explore ways to make globalization inclusive, so that the process can be seen to be fair for all, both between and within countries; to promote a more focused international dialogue on the social dimension of globalization; to build consensus among key actors and stakeholders on appropriate policy responses; and to assist the international community forge greater policy coherence in order to advance both economic and social goals in the global economy.

The report of the World Commission, A fair globalization: Creating opportunities for all, was released on 24 February 2004. It is available on the Commission's website www.ilo.org/public/english/wcsdg/index.htm.

A secretariat was established by the ILO to support the Commission. Among other tasks, it compiled information and commissioned papers on different aspects of the social dimension of globalization. The aim was to provide the Commission with documentation and data on a wide range of options and opinions concerning subjects within its mandate, without committing the Commission or individual Commissioners to any particular position on the issues or policies concerned.

Material from this background work is being made available as working papers, as national and regional reports on meetings and dialogues, and in other forms. Responsibility for the content of these papers and publications rests fully with their authors and their publication does not constitute an endorsement by the World Commission or the ILO of the opinions expressed in them.

\author{
Gerry Rodgers \\ Director \\ Policy Integration Department
}





\section{Preface}

The Technical Secretariat to support the World Commission on the Social Dimension of Globalization first prepared a synthesis of ILO activities on the Social Dimension of Globalization (published as Working Paper No. 1 in this series). Documentation on the work and outcomes of other major commissions, an ideas bank, a database and knowledge networks of experts and social actors were subsequently developed. These networks have dealt with several topics, including: inclusion at the national level for the benefits of globalization to reach more people; local markets and policies; cross-border networks of production to promote decent work, growth and development; international migration as part of the Global Policy Agenda; international governance (including trade and finance); the relationship between culture and globalization; and values and goals in globalization. Gender and employment aspects were addressed throughout this work. The Reports on the Secretariat's Knowledge Network Meetings are available on the Commission's web site or in a special publication from the ILO (ISBN 92-2-115711-1).

During the course of these activities, a number of substantive background papers were prepared, which are now made available for wider circulation in the Policy Integration Department's Working Paper series (Nos. 16 to 38), as well as on the Commission's website.

This paper was prepared by Dr. Humphrey of the Institute of Development Studies at the University of Sussex, UK. An earlier version was prepared for a Knowledge Network Meeting on Cross Border Networks of Production, organized by Susan Hayter.

Dr. Humphrey considers the way in which new forms of global coordination affect the possibilities for upgrading agricultural and manufacturing producers and traders in developing countries. The global value chain approach emphasizes new linkages in the global economy and the increasing level of trade in parts and components. The critical question is the contribution of such global production systems to sustainable increases in incomes and employment in developing countries. Do the new characteristics of global production systems help or hinder movement up the technological ladder by firms in developing countries? How does recognition of the fragmentation of global production and distribution systems affect country-level development strategies? Does a shift in perspective from firms as producers of final products to firms as part of value chains involving complex divisions of labour and inter-firm coordination create a need for new development strategies? Policies to stimulate and support the upgrading efforts of firms and groups of firms can be divided into three types: (i) policies that support upgrading irrespective of the specific nature of global value chains; (ii) policies that facilitate the participation of firms in globally dispersed production systems; and (iii) policies that support firm level upgrading in the context of the specific challenges. Global value chain analysis also points to specific policy areas that require attention. Another set of policy questions arises from the recognition that in the global economy firms in developing countries often form just one part of an international division of labour. Policies to facilitate the integration and coordination of activities that cross national boundaries are therefore equally required.

\section{Rolph van der Hoeven \\ Manager, Technical Secretariat World Commission on the Social Dimension of Globalization}

May 2004 



\title{
Upgrading in global value chains
}

\section{Introduction}

This paper considers the way in which new forms of global coordination affect the possibilities for upgrading agricultural and manufacturing producers and traders in developing countries. It addresses the issues of market access and the acquisition of technological capabilities, drawing data from studies of global value chains in a variety of sectors. ${ }^{1}$ It considers how different forms of insertion in the global economy facilitate or obstruct the potential for the acquisition of capabilities and market access, and the policy frameworks which might enhance upgrading opportunities.

The global value chain approach emphasizes new linkages in the global economy:

\begin{abstract}
The value chain view of global economic integration highlights that for many industries access to international markets is not achieved merely through designing, making and marketing new products. Instead, it involves gaining entry into international design, production and marketing networks consisting of many different firms. Understanding how these value chains operate is very important for developing country firms and policymakers because the way chains are structured has implications for newcomers. How can economic actors gain access to the skills, competences and supporting services required to participate in global value chains? What potential is there for firms, industries, and societies from the developing world to "upgrade" by actively changing the way they are linked to global value chains? (Gereffi et al., 2001:2)
\end{abstract}

Conceptions about what it means to be involved in global trade and the global economy have changed substantially in recent years. The traditional image of export activity for developing country firms would be an enterprise that designs, makes and exports a product. Now, the developing country exporter may work to a design supplied by an international buyer. Or the exporter may just produce a small part of the final product. Firms in developing countries may act as the organizers of geographically and organizationally fragmented supply systems, as is the case of companies such as Li \& Fung in the garment industry (Sturgeon and Lester, 2001: 46-49).

There is increasing recognition of this transformation. Many analyses of global trade have emphasized the increasing level of trade in parts and components and the growth of global value chains. The development of these new forms of coordination in the global economy is widely seen as contributing to the rapid rise in manufactured exports from developing countries over the past two decades. These changes have created a new environment with

\footnotetext{
${ }^{1}$ A variety of terminologies have been used to try and capture the development of new global production and distribution systems, including "global production networks" (Henderson et al., 2002), "international production networks" (UNCTAD, 2002b), "globalization of production" (Gourevitch et al., 2000), "global commodity chains" (Gereffi and Korzeniewicz, 1994) and "international value-added chain" (Kogut, 1984). This paper uses the term "global value chain" as it is derived analytically from the work of the global value chain initiative: for more information, see Gereffi et al. (2004) and http://www.globalvaluechains.org
} 
uncertain consequences for developing country firms. For development purposes, the critical question is the contribution of such global production systems to sustainable increases in incomes and employment in developing countries.

Do the new characteristics of global production systems help or hinder movement up the technological ladder by firms in developing countries? How does recognition of the fragmentation of global production and distribution systems affect country-level development strategies? Does a shift in perspective from firms as producers of final products to firms as part of value chains involving complex divisions of labour and interfirm coordination create a need for new development strategies?

The positive view of the potential contribution of these global linkages to upgrading and sustainable development was presented in UNIDO's Industrial Development Report $2002 / 2003$, at the beginning of the chapter on "Innovation and learning in global value chains":

Global value chains spanning functions, processes and countries provide a means for accelerating the development of enterprises and countries, providing openings that developing country enterprises can exploit to upgrade their capabilities. For such enterprises, or local clusters of enterprises, the task is to insert themselves into the wider networks. This takes discipline, to attain the higher world standards. It also takes an initial base of technological capability, built through purposive innovation and learning. But the effort should be worth it, for it offers access to markets and the knowledge of players in the world economy. (UNIDO, 2002: 105)

This passage emphasizes the two key elements of upgrading in the global value chain perspective: the acquisition of capabilities and access, not just to markets in general, but to particular marketing channels. The quote suggests that a certain minimum level of capability is required before access to global markets can be achieved. Nevertheless, once entry is gained there are learning effects within global value chains arising from supplier-buyer interactions. Entry into global value chains therefore has a positive impact on technological capability and upgrading. It should promote learning by firms in developing countries.

The same report also notes that the countries that have moved most rapidly up the competitive industrial performance (CIP) ranks are those that are integrated into global value chains:

In general CIP [competitive industrial performance] ranks changed little between 1985 and 1998 (...) Leaps in the rankings are nevertheless possible (...) The main cause of the large upward leaps appears to be participation in integrated global production networks, which sharply raises the share of complex products in exports. (UNIDO, 2002: 42)

An alternative perspective, which emphasizes the potential dangers for developing countries from increasing global integration, has been highlighted in the Trade and Development Report, 2002 (UNCTAD 2002b: 74-76): 
- The relocation of labour-intensive or unskilled assembly activities to developing countries may not raise overall skill requirements. This not only reduces the benefits in terms of incomes, but also reduces the potential for technological spillovers.

- Being part of an international production network (or global value chain) may leave developing country firms at the mercy of decisions made by the lead firms within these networks. Their continued involvement in the network and upgrading opportunities might depend on the strategic decisions of the lead firms.

- The development of these networks facilitates the entry of developing countries into global markets. Developing country firms need only to acquire capabilities in a limited range of operations, and even here they may receive support from global buyers. As a result, many new production sites can be integrated into the global economy and competition between them might provoke a race to the bottom.

These differing views are discussed in this paper, which is arranged in six further sections. The following two sections focus on new trends in the global economy and the challenge of upgrading. Sections 4, 5 and 6 then explore three ways in which integration into global value chains (and the current transformations of these value chains) affects upgrading possibilities. The final section provides policy recommendations for upgrading in the context of value chain linkages.

\title{
2. New forms of coordinating global production and distribution
}

Over the past few decades, developing country manufacturing exports have increased substantially, although a small number of countries account for a very large share of these exports. ${ }^{2}$ With the rise of developing country manufacturers, global manufacturing has become not only more dispersed geographically, but also more organizationally fragmented. And yet, at the same time, global production systems have become more closely coordinated than ever before.

Without doubt, one important driver of the development of coordinated global production has been transnational companies. Global levels of foreign direct investment (FDI) rose rapidly in the 1980s and 1990s, and transnational companies have integrated their dispersed production units more closely within regional and global divisions of labour:

\begin{abstract}
Another factor in the varying rates of expansion of trade in different products is the increased mobility of capital. This, together with continued restrictions on labour mobility, has extended the reach of international production networks in a number of products in which the production process can be partitioned into different segments that can be located in different countries according to their factor endowments and costs. Such arrangements have rapidly expanded trade in a number of products such as computers and office equipment; telecommunications, video and audio equipment and semiconductors; as well as clothing. They have also led to a greater involvement of developing countries in world trade in manufactured products. (UNCTAD, 2002b: 53)
\end{abstract}

\footnotetext{
${ }^{2}$ The ten leading developing country exporters of manufactured produce accounted for 76 per cent of developing country manufactured exports in 1985 and 86 per cent in 1998. Excluding China from the calculations reduces these figures to 69 per cent and 77 per cent respectively. The author is grateful to Sanjaya Lall of Oxford University for providing these data.
} 
The development of such systems has led to the increasing importance of trade parts and components, as opposed to finished products. This has led to an increasing interest by economists in the fragmentation of production (see, for example, the collection of papers in Arndt and Kierzkowski, 2001a) and in vertical specialization (Hummels et al., 1998: 82), defined as the import of parts and components which are incorporated into products that are subsequently exported. One early example of such vertical specialization would be Fairchild's pioneering shift of semiconductor assembly to Hong Kong in 1961 (Grunwald and Flamm, 1985).

Nevertheless, coordination of international production networks is by no means confined to the vertically-integrated but geographically dispersed operations of transnational companies. Organizational fragmentation, as well as the geographical fragmentation of value chains, is a feature of globalization. In the first place, transnational corporations have been de-verticalizing and outsourcing. This process is seen very clearly in the electronics and automotive industries. In electronics, firms such as Apple, Hewlett Packard, Ericsson and Alcatel have handed over much basic manufacturing, along with its associated supply chain management, to specialist companies (Sturgeon, 2002; Sturgeon and Lester, 2001). The global auto industry has been characterized by increased outsourcing by assemblers to first-tier suppliers, which have taken responsibility for designing and supplying modules and systems for vehicles (Humphrey and Salerno, 2000). In both cases, this has led to increasingly globalized supply systems able to provide parts and components to major customers at many points around the world.

Second, new drivers of globalization have emerged. In particular, global production systems and international trade in sectors such as clothing are frequently developed by non-manufacturing firms involved predominantly in design, marketing and retailing. One striking image of the new global economy is the expression "manufacturers without factories" (Gereffi, 1999: 46). These are global buyers involved in the design and marketing of products, and possibly in global logistics, but not in manufacturing. Among these firms, large retail chains, including supermarkets, have become particularly important in global trade. As Feenstra (1998: 38) notes, the largest importers of apparel into the United States in 1993 were retailers and brand name companies which between them accounted for 70 per cent of imports by the top 100 apparel importers.

The critical point here is the role of these companies in design, logistics and sourcing. While retailers may buy finished products, they often specify what is to be produced (product design), how it is to be produced (process specifications, quality systems, compliance with labour and environmental standards) and the time schedule. In other words, coordination across firm boundaries and across geographical space remains important even when the buyers are purchasing finished products. Coordination without ownership is a striking feature of the global economy, and this calls into question the dichotomy between vertical integration and arm's length market relationships which frequently characterizes analyses of fragmentation: 
Separability of ownership is an important determinant of the organizational structure of crossborder production sharing. Where separation of ownership is not feasible, multinational corporations and foreign direct investment are likely to play a dominant role. Where it is feasible, arm's-length relationships are possible and foreign direct investment is less important. (Arndt and Kierzkowski, 2001b: 4)

In practice, separation of ownership is by no means antithetical to explicit coordination in global value chains. This is seen particularly clearly in the global production and distribution of fresh food. The production of fresh crustaceans, fresh fish and fish preparations, and fresh vegetables is one of the most dynamic sectors of agricultural trade involving developing countries (UNCTAD, 2002b: 61), and the demands for food safety and rapid delivery are leading to the development of complex buyer-seller relationships involving extensive coordination in areas such as product design, quality systems, logistics and production scheduling. Such complexity is seen clearly in the highly organized trade in fresh vegetables between Africa and Northern Europe (see Box 1).

How does the development of complex global production systems affect upgrading opportunities for firms in developing countries? Does the emergence of complex buyersupplier relationships characterized by explicit coordination facilitate access to global markets and upgrading, or make it more difficult?

This issue can be addressed at both the micro and macro levels. At the micro level, global production systems affect market access and firm-level learning. On the one hand, insertion into value chains can facilitate the entry of developing country firms into export markets. They can specialize in production. They do not have to be concerned about such issues as product design, logistics or market requirements in importing countries. These issues are addressed by the buyers and their agents. Furthermore, the increasingly stringent requirements of global buyers in areas such as quality and delivery may offer firms opportunities to add value to products through the provision of "intangibles" relating to customer service. On the other hand, specialization in production activities within the value chain may leave developing country suppliers with a limited understanding of market requirements and few opportunities to develop capabilities in the areas of design and marketing.

At the macro level, it is clearly the case that East Asian economies have benefited enormously from export-oriented manufacturing, which has increased employment, led to rising wages in manufacturing (on the whole) and reduced poverty. Furthermore, the new generation of East Asian companies have come to occupy strategic positions in global value chains, either acting as intermediaries between global buyers and local manufacturers, or becoming international manufacturers themselves. The consequences for other countries are less clear. Are latecomers to the global economy absorbed or excluded by global value chains? And do existing value chain structures offer the same possibilities for integration and upgrading as those in existence 20 or 30 years ago? 


\section{Box 1}

\section{Increasing coordination in the fresh vegetables trade}

The trade in fresh vegetables between Kenya and the United Kingdom grew very rapidly in the 1980s and 1990s. Large quantities of temperate vegetables, such as peas and beans, are now air-freighted to the United Kingdom throughout the year. In the early 1980s, the business was organized on the basis of predominantly arm's length market relationships. Small traders bought produce at the farm gate or in wholesale markets in Kenya and channelled it through import agents in the United Kingdom, who sold it on wholesale markets. From there, produce went to retailers and other outlets.

By the late 1990s, over 75 per cent of the fresh vegetables imported from Africa into the United Kingdom were sold through a small number of supermarket chains. The supermarkets do not buy products on wholesale markets. They work with United Kingdom importers, who in turn have close relationships with exporters in Kenya, other parts of Africa and other parts of the world. The business relies on complex relationships. One-year agreements are made on overall levels of purchases and price indicators, although these are constantly modified in the face of demand fluctuations. Quality systems and procedures are agreed upon and enforced through regular monitoring. New products are developed through cooperation between exporters, importers and retailers.

Three factors drive these changes:

- Increased emphasis by retailers on product differentiation and innovation (new products, new packaging, greater processing). Fresh vegetables have been a key element of non-price content competition between large retailers in the United Kingdom. Supermarkets cannot lead product innovation if they do not actively coordinate the supply chain.

- An emphasis on quality and freshness, leading to greater coordination of activities along the value chain so that products can reach the United Kingdom within 48 hours of being harvested.

- Greater concern with food safety, arising partly as a result of the 1990 Food Safety Act in the United Kingdom, which placed a requirement on companies to show "due diligence" in the manufacture, transportation, storage and preparation of food and held companies accountable for lapses in their suppliers' performance. These concerns relating to supply chain management were reinforced by the European Union's programme to harmonize maximum pesticide residue levels (MRLs) in food, which began in 1993, and by increased attention to labour and environmental standards, reflected in the development of company and sectoral initiatives, such as the EUREP GAP (Good Agricultural Practice) standard. *

* $\quad$ EUREP is a voluntary association of European food importers and retailers. Its GAP (Good Agricultural Practice) framework sets out a series of requirements, focusing on pesticides, chemical use, fertilizers, traceability and labour. The Protocol (EUREP 2001: 3) emphasizes record-keeping and provides for independent verification by approved bodies.

Source: This case is based on Dolan and Humphrey (2000).

\section{Upgrading}

Entering export markets for the first time is a major challenge for many firms in developing countries. It demands new skills and knowledge, for example concerning bureaucratic procedures, national standards and requirements, marketing channels and consumer tastes.

The extent of the challenge is outlined by Hobday. In his analysis of the problems facing the "latecomer firm" in the global economy he identifies competitive disadvantages arising from its distance from the technological frontier and from global markets and consumers: 
[A] latecomer firm is defined as a manufacturing company (existing or potential) which faces two sets of competitive disadvantages in attempting to compete in export markets. The first is technological in character. Located in a developing country, a latecomer firm is dislocated from the main international sources of technology and R\&D. It operates in isolation from the world centres of science and innovation and is behind technologically, lacking in research, development and engineering capability (...). The second disadvantage concerns international markets and demanding users. To add to its technological difficulties, the latecomer firm is dislocated from the mainstream international markets it wishes to supply. These are mostly located in the advanced countries, rather than developing countries. Typically a firm will confront underdeveloped, small local markets and unsophisticated users. (Hobday, 1995: 33-34)

A similar argument has been advanced by Keesing and Lall (1992), who point out that producers in developing countries are expected to meet requirements that frequently do not (yet) apply in their domestic markets. This creates a gap between the capabilities required for the domestic market and those required for the export market.

Many firms in developing countries have bridged this gap. The critical question is, however, how value chain relationships affect the process of learning, innovation and the acquisition of technological capabilities. Is upgrading relatively easy once firms are within global value chains? Or, in the words of Hobday (1995: 33), is technological learning "a dynamic, difficult and costly process", and one that needs strategic interventions by firms and support from governments and international agencies?

The reference point for the literature on industrial upgrading is the East-Asian experience. ${ }^{3}$ This has often been analysed in terms of the sequence of acquisition of functional capabilities, as shown in Figure 1.

These upgrading strategies require not only the acquisition of capabilities, but also involve changing relationships with buyers and markets. The marketing implications of the sequence of technological learning and upgrading followed by successful East Asian firms have been described by Wortzel and Wortzel (1981). Based on a study of locally-owned exporting firms in five countries (the Republic of Korea, Hong Kong, Taiwan (China), Thailand and the Philippines), they identified five stages of export marketing development. Each stage differs according to the nature and extent of the promotion and distribution carried out by the exporter, and with respect to production and design:

Stage one. Exporting is "initiated by an importer searching for a low cost facility capable of performing certain specific operations (...). The importer usually makes all external design decisions, including appearance and packaging, and may also determine the internal design of the product. The importer takes quality control responsibility by inspecting finished goods and, often, work in process. He also arranges for shipping. The local producer is simply a seller of production capacity whose success depends largely on the prices he quotes." (Wortzel and Wortzel, 1981: 52)

\footnotetext{
${ }^{3}$ The term "industrial upgrading" is frequently used in the literature (see Gereffi, 1999), as it is in this paper. However, it should be noted that the issues can apply equally to agriculture, and some of the examples in this paper are taken from agriculture and horticulture.
} 
Stage two. "The Stage II firm has developed some internal design capabilities. It also has some understanding of external design and packaging, but it still needs help from its customers in setting specifications (...). It has begun to develop a rudimentary sales and marketing organization.” (Wortzel and Wortzel, 1981: 52)

\section{Figure 1 Upgrading trajectory}

\begin{tabular}{|cl|}
\hline Assembly & $\begin{array}{l}\text { The focus is on production alone, often following } \\
\text { buyers' specifications and using materials supplied } \\
\text { by the buyer. In the garments sector, this would be } \\
\text { described as "cut-make-and-trim". }\end{array}$ \\
\hline Original equipment manufacture & $\begin{array}{l}\text { The supplier takes on a broader range of } \\
\text { manufacturing functions, possibly including the } \\
\text { sourcing of inputs and logistics functions. The } \\
\text { buyer is still responsible for design and } \\
\text { marketing. In the garments sector, this would be } \\
\text { described as "full package" production. }\end{array}$ \\
\hline Original design manufacture & $\begin{array}{l}\text { In addition to manufacturing, the supplier carries } \\
\text { out parts of the design process, possibly in } \\
\text { collaboration with the buyer. In the most } \\
\text { advanced cases, the buyer merely attaches its } \\
\text { own brand, or "badge" to a product designed } \\
\text { and made by the supplier. }\end{array}$ \\
\hline $\begin{array}{l}\text { (ODM) } \\
\text { Original brand manufacture }\end{array}$ & $\begin{array}{l}\text { The supplier designs, produces and markets its } \\
\text { own products under its own brand. It no longer } \\
\text { relies on a buyer for these functions. }\end{array}$ \\
\hline (OBM) &
\end{tabular}

Stage three. "The Stage III firm still produces to its customers' orders, but it has developed enough internal design capability to produce export quality merchandise with little or no assistance from its importer customers in setting internal and external design specifications (...) the [Stage III] firm may try to broaden its range of products, to 'trade up' its product line, or to increase the number of customers for its existing list of products. In any event, the Stage III firm begins to take steps to gain more control over its product lines, its sales volume, its customers and the prices it obtains." (Wortzel and Wortzel, 1981: 52-54)

Stage four. "While the Stage IV firm may still devote some proportion of its production capacity to contract manufacture, it has begun to produce and market its own products (...) The Stage IV firm's most important competitive weapon is still price, especially if it is competing in product categories such as consumer electronics and athletic shoes (...) The Stage IV [newly industrialized countries] NIC manufacturers' exports will most often be employed as promotional items. Retailers will use television sets from the NICs, for example, as the lowest priced items in the assortment they offer consumers (...) Since the Stage IV firm chooses what it will produce, its product design and product development

4 See Mortimore (2002: 296-97) for a discussion of "full package" production in East Asia. 
capabilities are more elaborate than those of the Stage III firm." (Wortzel and Wortzel, 1981: 54-55)

Stage five. "[T] indigenous to the advanced countries to which it exports (...) The Stage V firm will have a marketing and sales organization similar to that of the indigenous firms with which it competes." (Wortzel and Wortzel, 1981: 55-56) The authors, writing the article at the end of the 1970s, considered Stage V not to have been achieved by firms in the newly industrialized countries. In the course of the 1990 s, some leading firms in these countries did reach this stage.

This model of upgrading stages is constructed from the viewpoint of firms in developing countries. The upgrading process is seen as one in which firms acquire capabilities and, once they have been acquired, the firms are able to find foreign buyers wishing to acquire products embodying these capabilities. In this context, much of the debate about economic development in East Asia has revolved around dichotomy of "market vs. State". From the "market" perspective, ensuring that the economic fundamentals are right and limiting the role of the State to education, defence and the rule of law is the route to economic success. Liberalizing the domestic market, trade and capital flows is part of the process of unleashing development potential. The "State" perspective highlights the role of the State in steering development and in promoting and shaping industrial development in the Republic of Korea and Taiwan (China). A combination of selective protectionism and the promotion of manufacturing capabilities through national and local systems of innovation explains the success of these economies.

In both cases, successful insertion into the global economy is seen as a result of "supplyside" developments. Developing country firms acquired the competences to compete successfully in global markets. A first step towards bringing buyers into the analysis was provided by Hobday (1995: 40), who explicitly matched the advance of technological capabilities shown in Figure 1 with a series of marketing stages derived from Wortzel and Wortzel. In both cases, it is argued that as firms acquire new capabilities, they need to find new markets. The development of technological and marketing capabilities are interlinked. On the one hand, selling into markets and interacting with customers can stimulate processes of learning, both in terms of creating new requirements to which the enterprise has to respond, and the transfer of knowledge. On the other hand, as firms develop their technological capabilities, they need to change the nature of their insertion into value chains in order to be able to use these capabilities.

Linking technological capabilities and marketing strategies is only the first step. Recent work on East Asian development has also recognized the critical role played by buyers in seeking out suppliers and developing their competences. As a result of these initiatives, new export opportunities have been created, sparking processes of rapid export-oriented development. In other words, buyers are placed at the centre of upgrading trajectories.

This shift in perspective can be seen in two quite different bodies of work. The first comes from analyses of the early development of the electronics industry in the Republic of Korea. These analyses emphasize the way in which manufacturing in the Republic of Korea was linked both to the production and sourcing strategies of Japanese firms and to buyers in the North American market. According to Hobday, Japanese firms played a critical role in developing the industry by setting up operations in the Republic of Korea. 
They formed joint ventures with local companies, such as Samsung and Goldstar, as well as setting up wholly-owned subsidiaries. By 1975, foreign firms accounted for 64 per cent of output in the electronics industry in the Republic of Korea, and 74 per cent of electronics exports. Of these exports, 51 per cent were from wholly foreign-owned enterprises and 23 per cent from joint ventures (Castley, 1997-98: 37).

These exports were largely directed at the North American market. In 1974, the North American market bought 64 per cent of all electronics exports from the Republic of Korea, and Japan a further 25 per cent (Castley, 1997-98: 42). In other words, the rapid development of the electronics industry in the Republic of Korea was driven by upstream and downstream relationships with Japan and the United States. Japanese firms imported machinery and components from Japan and either set up joint ventures or subcontracted assembly to firms in the Republic of Korea. The outputs were then exported to the United States, and to a lesser extent to Japan, often using the brands and distribution channels of the Japanese companies.

Of course, this was only a first step, and the long-term sustained growth of the electronics industry and others like it would have been impossible without government support for local firms and the development of local technological capabilities. Government policy was clearly important in promoting the growth of the Chaebols, which were able to take ownership of the joint ventures established by Japanese companies in the Republic of Korea. $^{5}$

Even after the shift in ownership, firms such as Samsung, Lucky-Goldstar and Daewoo retained strong links with Japanese transnationals and used the same pattern of value chain linkages to gain access to export markets. Much of their production took the form of original equipment manufacture (OEM). The firms in the Republic of Korea produced products to largely Japanese designs, using many parts imported from Japan and selling the products under the Japanese partner's brand name in the United States. Through licensing agreements, subtracting arrangements and joint ventures, the firms in the Republic of Korea were able to acquire technology in the 1960s and 1970s and then to complement it with their own technological investments.

From this perspective, global value chain linkages played a decisive role in the development of the Asian newly industrialized economies. The linkages promoted this development, rather than arising as a consequence of the development of manufacturing in these countries. The same process has been replicated in other parts of Asia. The sudden and massive shift of athletics footwear production destined for the United States market from the Republic of Korea and Taiwan (China) to China and Indonesia would be impossible to understand without reference to the role of United States buyers and of manufacturers in Taiwan (China) and the Republic of Korea in relocating production and creating new and complex regional divisions of labour. No country could have conquered a huge share of the world's largest athletics footwear market in such a short period of time if local companies had had to develop their own design and manufacturing capabilities, build new factories and develop their own distribution systems and brand identities.

5 According to Hobday, employment in the foreign electronic subsidiaries in the Republic of Korea fell by one-third between 1976 and 1985, even though overall employment in the sector rose by 50 per cent (1997-98: 53). 
A more general argument about the importance of buyers in the rapid growth of exportoriented manufacturing in the Asian newly industrialized countries has been put forward recently by Hamilton et al. (2003). Drawing heavily on earlier work on global value chains (for example, Gereffi, 1999; Gereffi and Korzeniewicz, 1994), they argue that the critical driver of the rapid early development of manufacturing industry in both Taiwan (China) and the Republic of Korea was demand from global brand name companies and retailers importing differentiated products into the United States. The crucial point is that manufacturers in East Asia were able to respond to the new needs of brand name companies and retailers, initially taking on the role of specifications subcontractors, and then developing their own capabilities and moving into "full-package" supply.

Hamilton et al. argue that the early rapid growth of the two countries in the late 1960s and early 1970s was driven by exports to the United States of differentiated manufactured goods (2003: 11). Not only was the United States the main export destination for their manufactured goods, accounting for almost half of their manufacturing exports, but the exports were highly concentrated in a small number of product lines. Using highly disaggregated, seven-digit data, they show that:

- The sectors at the forefront of the retail revolution in the United States were also the leading export sectors in the Republic of Korea and Taiwan (China) from the mid1960 s to the mid-1980s. The codification of products through such "lean retailing" practices as uniform product codes and the standardization of sizes, colours, weights and communication systems greatly facilitated the sourcing of differentiated products from overseas suppliers.

- Exports were concentrated in a small number of product lines. In the 1970s, between 25 and 50 per cent of all manufactured exports were concentrated in just ten sevendigit products.

- These products were customized to the requirements of foreign buyers: "Until 1998, approximately 95 per cent of garment exports were produced under contract to foreign firms, rather than under Korean-owned labels." ${ }^{6}$ The same has also been true for later generations of exports, such as personal computers and peripherals.

- There are sudden and rapid shifts in the types of products exported, which indicates changing buyer preferences and the responsiveness of local manufacturing to these changes. If the producers had taken the initiative of supplying different products, the shifts would have been more gradual.

The role of global buyers does not account for the whole story of rapid and sustained development in the Asian newly industrialized economies. One obvious example of industrial development sponsored by the State rather than stimulated by foreign buyers is the development of the steel industry in the Republic of Korea. Furthermore, emphasizing the role of foreign buyers does not in any way detract from the importance of investments by the State and by firms in the acquisition of technological capability by the firms themselves. The case of the success in the global market of microwave ovens from companies in the Republic of Korea has been well documented. The ability of Samsung to become a supplier of microwave ovens to Sears and General Electric (sold under their own labels) was the result of a strategy of investment in research and development; a willingness to buy in key parts (above all the magnetron, which is the heart of a microwave oven), until it was possible to buy an ailing producer of this product in the United States

6 Hamilton et al. (2003), citing Lee and Song (1994). 
and ship the manufacturing facilities to the Republic of Korea; and the enormous efforts expended upon learning about the requirements of consumers in export markets (Magaziner and Patinkin, 1989).

Nevertheless, Hamilton et al. demonstrate conclusively the importance of foreign buyers (particularly from the United States) in promoting exports of differentiated manufacturing products and their overall importance in the development of Taiwan (China) and the Republic of Korea. While no other countries come anywhere near to matching the sustained success of the Asian newly industrialized countries, it is clear that global buyers have played an important role in promoting upgrading in other countries. The UNIDO Industrial Development Report, 2002 concludes that, where there were significant improvements in the ranking of countries on its competitive industrial performance index between 1985 and 1998, "[t]he main cause of the large upward leaps appears to be participation in integrated global production networks, which sharply raises the share of complex products in exports" (UNIDO, 2002: 42).

Nevertheless, upgrading is not straightforward. If it were, there would not be so many countries with poorly developed agricultural and manufacturing systems. There are many reasons for these deficiencies. However, the changing nature of global value chains presents new challenges for developed and developing countries alike.

\section{Global buyers, access to global markets and upgrading}

It has been suggested above that entering export markets for the first time is a major challenge for many firms in developing countries. If global value chains link together specific suppliers and specific buyers, then the barriers become much easier to overcome. Knowledge about markets, production processes and logistics can be acquired. The global buyer can offer significant order volumes and more stability (in the short term) in relation to both the quantities ordered and the prices paid. Furthermore, the upgrading support that the buyer can offer is directly relevant to the needs of the firm for the market that it is supplying.

However, this facilitation of entry may come at a price. To what extent may developing country producers become locked into narrowly-defined roles (with correspondingly limited technological capabilities) within global value chains?

\subsection{Upgrading by buyers}

Why would global buyers be prepared to invest in upgrading the capabilities of developing country firms? In simple terms, they will provide assistance to developing country firms if the costs of this assistance are more than offset by the benefits of integrating these firms into global value chains. The developing country firms must be able to offer advantages typically lower costs or access to scarce resources - that cannot be accessed as cheaply or as flexibly through foreign direct investment. 
One example of such an investment in local suppliers is presented in Box 2. The buyer was looking for new sources of organic cocoa, which at the time was in short supply. It was willing to invest in a cooperative in order to bring it up to the required standard. In this case, the option of buying through arm's length market relationships was not feasible. There was a shortage of supply. Generally speaking, organic produce is grown in Latin America by small farmers, often organized in cooperatives (Damiani, 2002). Direct investment in a plantation may not have been cost-effective, even if land had been available. In addition, this would have increased capital outlay and tied the investor more directly to the uncertainties of the market for organic cocoa.

\section{Box 2}

\section{Facilitating entry to the value chain: Organic cocoa}

Finding (or being found by) the right buyer can be a short cut to exporting. Take the case of organic cocoa. If a group of small farmers somewhere in Latin America wanted to export organic cocoa to Europe, the challenges might be formidable. What organic certification is recognized in Europe? What varieties of cocoa are preferred? What times of year are market conditions most favourable? What are the tariff levels and documentation requirements? Is shipping available?

In some cases, export promotion or import facilitating agencies are able to provide the answers to these questions. Perhaps an agent can be found who knows about the market. Local rural development agencies may see it as part of their role to provide this type of support. However, answering these many different questions requires the mobilization of a lot of expertise.

For one group of cocoa producers in the Caribbean, these problems are being solved by a major European chocolate maker. Organic chocolate is in big demand. There is a shortage of supply, and so big buyers are prepared to invest their own money in developing new sources of supply. For some buyers, investing in cooperatives and developing a fair trade image is an additional attraction. The European buyer is investing in organic production with a group of cocoa farmers. Its experience in importing cocoa means that it knows the answers to many of the questions listed above. The cocoa producers can concentrate on producing cocoa and the buyer organizes everything else. An additional benefit is that they have supply contracts lasting a whole year, with a stable price.

This can be seen as a short cut into the export market in the short term. In the longer term, it might become a trap. The exporters might remain ignorant of European market requirements and become dependent on one buyer. Over time, organic cocoa may become more plentiful on the market and the buyer will find other sources. Will the above cocoa cooperative be able to find other buyers, markets and distribution channels?

Source: author's research.

Such processes are not confined to agriculture. Schmitz describes how the entry of Brazilian shoe producers into export markets, particularly in North America, involved a clear division of labour between global buyers (wholesalers, retailers or export agents) and the producer firms:

These export agents were not just buyers. In addition to negotiating with the US retail chains on one hand and the Brazilian producers on the other they carried out the following functions: they studied the market which necessitated visiting shoe shops in the United States and Europe as well as international shoe firms. They developed models which required setting up model shops in the [Sinos] Valley to produce samples. They inspected product quality and production schedules on site; they provided technical assistance; they organized the transport and payment arrangements. (Schmitz, 1995: 14) 
This process led to a rapid expansion in the cluster of shoe companies in the Sinos Valley. Between 1972 and 1987, shoe industry output in the Sinos Valley rose from 42 million pairs to 174 million pairs. In 1972, most of the Valley's production was directed at the Brazilian market. By 1987, two-thirds of production was exported (Bazan and Schmitz, 1997: 20-21). ${ }^{7}$

Such processes may provide conduits for the transfer of knowledge that cannot easily be acquired in other ways. On the basis of a study of Mexican garment manufacturers and their North American buyers, Dussel Peters et al. suggest that potential suppliers are "virtually tutored" by their buyers and that "the learning process involves what is known in the literature variously as practical, implicit, or tacit knowledge. Its essential characteristic is that it is difficult to transmit verbally or in written instructions and instead is taught by demonstration on the job as production is carried out" (2002: 232). While this account refers in particular to process knowledge used in production (as opposed to knowledge about markets), the important point is that tacit knowledge is very difficult to transfer. By definition, it cannot be learned from manuals. It can also be argued that consultants are often poor transmitters of such knowledge. The buyer-supplier relationship is therefore particularly important.

If buyers make this type of investment in suppliers, how can they guarantee a return on their investment? In many cases, the skills transmitted are generic and can be applied to many buyers and markets. Why should the suppliers not sell their newly acquired competences to other companies, including the direct competitors of the firm making the investment? There are two ways to approach this issue. One possibility is that buyers "lock in" suppliers by making them transactionally dependent. If a buyer takes a large proportion of a supplier's output, then the costs of switching to new suppliers are high. In some cases, contract terms may exclude suppliers selling into the same market as the buyer. ${ }^{8}$ This type of strategy is described by Schmitz (1999).

Conversely, Dussel Peters et al. suggest that garment buyers did not adopt this strategy in Mexico. Cases of "defection" to other buyers were, in practice, evident. They argue that the buyers most able to make this type of investment are brand name producers with a worldwide sourcing strategy. Their control of brands provides them with levels of profit which enable them to pay higher prices to their contractors, giving an incentive to the supplier to maintain supply and providing the buyer with a return on its investment. In so far as suppliers are locked in, it is through financial support, as the support package "generally includes access to material supplies at favourable credit terms and to credit itself” (2002: 234).

\footnotetext{
${ }^{7}$ Over time, the role of export agents was supplanted to some extent by buyers working directly for the major United States importers. Nevertheless, the buyers' role and the division of labour remained the same. Agents are often used when sourcing first begins. As scale and the likelihood of continuing supply increase, foreign buyers work more directly with producers. According to Bazan and Navas-Alemán (2001), United States branded retailers had five offices in the Sinos Valley, but there were 88 export agents of varying sizes operating in the Valley as well.

${ }^{8}$ According to Bair and Gereffi, who analysed blue jean manufacturers in the Mexican city of Torreón: "No manufacturer in Torreón markets its own apparel brands in the United States (...) and no Torreón producer of a US brand is able to sell its branded output directly in Mexico (everything is exported to the United States)" (2001: 1895).
} 


\section{Box 3}

\section{Tying suppliers to buyers}

One extreme example of a lock-in strategy adopted by a buyer to make sure that it gains the benefit from its investment in suppliers is reported by Damiani (2002) in his study of organic agriculture in Latin America. A buyer interested in purchasing organic produce from smallholders helped them to acquire organic certification. It guaranteed its investment by retaining control of the organic certificates. If the smallholders tried to supply other companies with organic produce, they would have no proof of their certification.

\subsection{Limits and vulnerabilities of buyer-promoted upgrading}

The limits to the process of buyer-promoted upgrading have been emphasized by Humphrey and Schmitz. They start by distinguishing between types of upgrading that can occur in value chains (2002: 1020):

- Process upgrading: firms can upgrade processes, transforming inputs into outputs more efficiently by re-organizing the production system or introducing superior technology.

- Product upgrading: firms can upgrade by producing products generating more value added per employee. This upgrading involves changing the firm's position in product markets. This can be achieved by changing customers or through a repositioning of the value chain, shifting the whole chain to higher value products.

- Functional upgrading: firms can acquire new functions in the chain, such as design or marketing. This involves changing the inter-firm division of labour within the chain or moving to another chain.

Analysis of experiences such as the Sinos Valley shoe cluster described above leads to the following conclusions: ${ }^{9}$

- Buyer-promoted upgrading is likely to lead to incremental product and process upgrading. These are the areas in which improved capabilities for newly-integrated producers give the greatest return to global buyers.

- Buyers are much less likely to promote radical, or discontinuous, leaps in capability.

- Buyers who make suppliers transactionally dependent on them will oppose upgrading if this creates opportunities for suppliers to acquire a broader range of customers. Opposition to functional upgrading is likely to be particularly strong if the buyers are traders which might be by-passed by suppliers if the latter gain the ability to work directly with developed country customers.

- Lead firms in global value chains may support the acquisition by suppliers of competence that they regard as non-core. For example, leading global buyers may wish to outsource activities such as logistics to other firms in the value chain.

\footnotetext{
${ }^{9}$ These conclusions are based on the broader analysis in Humphrey and Schmitz (2000 and 2002).
} 
However, they will not invest in the acquisition of such a capability. The supplier has to develop the capability and show its relevance to the buyer.

- Investment in supplier capability is probably transitory. It occurs when new sources of supply are opened up, or when the market demands new capabilities. Once capabilities become widespread among the supply base, there is no need for buyer investment.

The risks of being locked into low value activities within the value chain can be illustrated by the case of the Sinos Valley shoe producers. The international traders and buyers of footwear in the Valley created a sustained period of expansion, which increased output and employment and led to the emergence of a number of large vertically-integrated firms. These firms were specialized, focusing predominantly on the sourcing of inputs and the production process. They did not require design capabilities.

This specialization was so evident that global buyers had clear perceptions of the strengths and weaknesses of Brazilian shoe firms compared to the global leader in the leather footwear industry, namely Italy. The comparison is shown in Figure 2. According to twelve global buyers interviewed by Schmitz and Knorringa (1999), Brazilian suppliers were compared favourably to Italian suppliers on price and dealing flexibly with large orders, and more or less matched them with regard to quality, response time, punctuality and coping flexibly with small orders. However, as is evident from Figure 2 below, by far the largest gap in supplier appraisals of the two countries was on the question of innovative design. On a scale of zero to five, Italy scored almost five, while Brazil scored less than three. Italy attained its highest score on this variable, while Brazil scored its lowest.

\section{Figure 2 Performance comparison, Brazil-Italy}

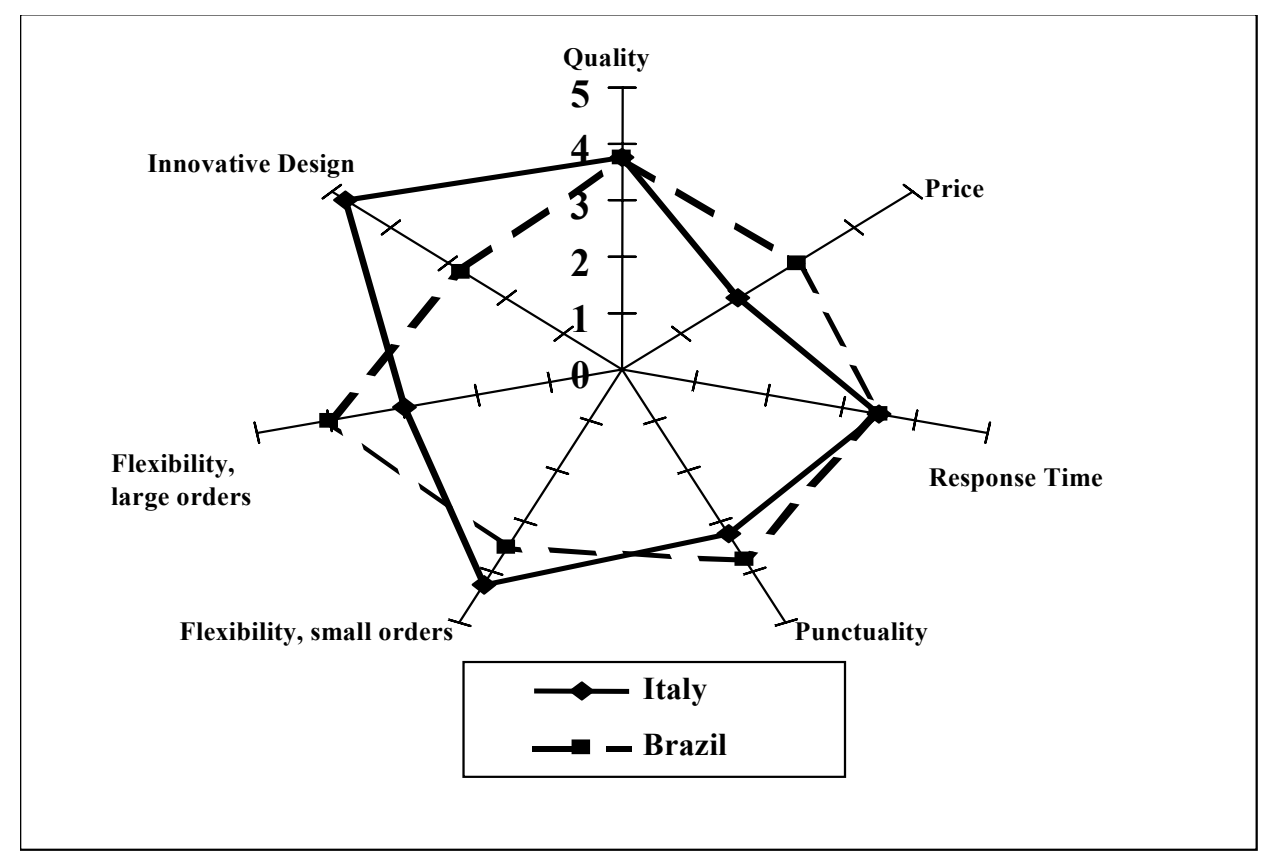

Source: $\quad$ Schmitz and Knorringa (1999: 11).

These differences in assessments by global buyers reflect the way in which Brazilian producers were integrated into the global market. Footwear designs were supplied by the buyers. The most successful exporters did not have to develop design capabilities, and in 
the Sinos Valley shoe cluster as a whole, the education and training of design experts was weak.

This weakness became a serious problem at the end of the 1980s, when North American footwear buyers began to source shoes in China. According to Schmitz (1999: 1632-33), United States footwear imports from China increased seventeen-fold between 1987 and 1997, which put pressure on Brazilian producers. Ideally, they should have moved upmarket, producing shoes of higher value and using capabilities not available to Chinese producers, but there were three obstacles to this strategy, all of them arising from global value chain linkages:

- The Chinese producers were themselves linked to companies in Taiwan (China) that were experts in shoe production. These firms could supply designs, quality control, logistics expertise and links to buyers. What had enabled the Brazilians to enter the global market in the early 1970s was facilitating competition from Chinese producers and their Taiwanese partners at the end of the 1980s. The Brazilians could not rely on production expertise alone (the strengths indicated in Figure 2) to provide them with competitive advantage. The Taiwan-China linkage combined cheap labour and footwear expertise.

- The leading firms within the Sinos Valley shoe cluster all sold most, if not all of their output to a small number of North American buyers. Finding new types of buyers and new markets was therefore a major challenge and risk for them.

- Routes to higher value-added market niches require new capabilities. If the Brazilian manufacturers were to produce footwear aimed at more sophisticated markets, they needed to move from original equipment manufacture (OEM) for their global buyers to own-design manufacture (ODM) or own-brand manufacture (OBM). Large-scale exports to North American buyers did not provide them with the experience and expertise needed for ODM and OBM.

The case of the Brazilian shoe industry has much broader implications for development and upgrading strategies in the context of global value chains. The entry of China into global markets and its significant role in developing country exports across broad ranges of manufacturing products presents a challenge to developing countries.

The extent of the impact of China on the exports of other developing countries can be seen in Figure 3, which provides information on China's exports compared to those of leading developing country exporters of manufactured products. Overall, China's manufactured exports rose from US\$128 billion in 1985 to US $\$ 1,084$ billion in 2000. In 1985, China exported 4.7 per cent of the total manufacturing exports of the ten leading developing country exporters (ranked according to their exports in 2000). By 2000, the Chinese share of total exports of these ten leading developing country exporters of manufactured products had increased to 21.2 per cent.

Figure 3 also breaks down manufactured exports into four categories, using a typology based on technological intensity developed by Sanjaya Lall. ${ }^{10}$ It shows that by 2000 China was the leading developing country exporter of products at all technological levels. While

${ }^{10} \mathrm{~A}$ description of the categories and industries that fall into each of these categories can be found in UNIDO (2002: 30). 
its dominance was greatest in low technology manufactures (such as garments, footwear, toys, furniture, simple metal and plastic products), in which it exported slightly more than half of the total exports of the top ten developing country exporters, in medium and high technology manufactures China accounted for approximately 20 per cent of the exports of the top ten developing nations.

The growth of Chinese exports poses a problem for developing countries competing directly with them, as discussed by Schmitz (1999) in the case of shoes. However, China also offers opportunities for countries and firms that are able to upgrade and occupy complementary positions in global value chains. One example from footwear is the role of companies in Taiwan (China) and the Republic of Korea in developing the production of athletics shoes in China for the North American market. Although production of this item shifted rapidly to China from Taiwan (China) and the Republic of Korea at the end of the 1980s, with the Chinese share of the United States market rising from less than 2 per cent in 1988 to over 30 per cent in 1992 (Lim, 1993: 570), firms in Taiwan (China) and the Republic of Korea continued to play an important role in product development, component supply and logistics. Just as United States firms such as Fairchild maintained their overall competitiveness in the 1960 s by relocating labour-intensive semiconductor assembly to Hong Kong, so firms in North America, Taiwan (China) and the Republic of Korea continue to benefit from the athletics shoe industry by finding profitable roles within the overall value chain. 
Figure 3 China's share of exports of leading developing country exports of manufactures by type of manufactures (US\$ million)

\begin{tabular}{|c|c|c|}
\hline & 1985 & 2000 \\
\hline \multicolumn{3}{|l|}{ All manufactured exports } \\
\hline China & 6,049 & 229,247 \\
\hline Korea, Rep. of & 29,025 & 166,451 \\
\hline Taiwan, China & 29,093 & 144,902 \\
\hline Mexico & 8,627 & 143,595 \\
\hline Singapore & 19,014 & 132,509 \\
\hline Top ten & 127,993 & $1,083,822$ \\
\hline China share of top 10 exporting country exports (\%) & 4.7 & 21.2 \\
\hline \multicolumn{3}{|l|}{ Resource-based manufactures } \\
\hline China & 3,702 & 23,385 \\
\hline Korea. Rep. of & 2,316 & 16,904 \\
\hline Indonesia & 3,265 & 13,076 \\
\hline Brazil & 5,743 & 13,023 \\
\hline Singapore & 5,976 & 12,111 \\
\hline Top ten & 34,838 & 127,452 \\
\hline China share of top 10 exporting country exports (\%) & 10.6 & 18.3 \\
\hline \multicolumn{3}{|l|}{ Low technology manufactures } \\
\hline China & 10,830 & 161,116 \\
\hline Taiwan, China & 16,167 & 32,140 \\
\hline Korea, Rep. of & 12,083 & 23,791 \\
\hline Hong Kong, China & 11,185 & 22,183 \\
\hline Mexico & 1,555 & 21,519 \\
\hline Top ten & 58,640 & 320,216 \\
\hline China share of top 10 exporting country exports (\%) & 18.5 & 50.3 \\
\hline \multicolumn{3}{|l|}{ Medium technology manufactures } \\
\hline China & 2,108 & 58,610 \\
\hline Mexico & 4,790 & 56,280 \\
\hline Korea, Rep. of & 5,384 & 40,952 \\
\hline Taiwan, China & 6,939 & 36,786 \\
\hline Malaysia & 1,015 & 13,340 \\
\hline Top ten & 31,548 & 256,817 \\
\hline China share of top 10 exporting country exports (\%) & 6.7 & 22.8 \\
\hline \multicolumn{3}{|l|}{ High technology manufactures } \\
\hline China & 709 & 75,829 \\
\hline Taiwan, China & 5,348 & 66,926 \\
\hline Malaysia & 2,819 & 54,491 \\
\hline Korea, Rep. of & 3,563 & 53,903 \\
\hline Singapore & 4,376 & 49,591 \\
\hline Top ten & 24,232 & 406,404 \\
\hline China's share of top 10 exporting country exports (\%) & 2.9 & 18.7 \\
\hline
\end{tabular}




\subsection{Market diversification and learning}

The extent of this challenge is not quite as daunting as it might appear. In particular, there is ample evidence that firms frequently sell to diverse markets and may be able to apply the knowledge and capabilities acquired in one market to new markets and customers. Two examples can illustrate this point, one taken from the textile industry in India and the other from the Sinos Valley shoe cluster.

The woollen knitwear cluster in India faced a particularly severe challenge following the collapse of export markets in the former USSR at the beginning of the 1990s. ${ }^{11}$ In the 1970 s and 1980s, the socialist States were by far the largest destination for exports of woollen knitwear from India, and almost all the export trade came from the Ludhiana woollen knitwear cluster. By the late 1980s, a considerable portion of Ludhiana's output of woollen knitwear consisted of low-quality, mass produced products directed at the Soviet market. At the beginning of the 1990s, the cluster was hit by the collapse of export markets in the former USSR and Eastern Europe and by India's trade liberalization programme. Contrary to expectations, the cluster reacted well, as summarized in Box 4. Companies switched to the European and North American markets, even though the requirements of these markets were much more stringent in terms of design, small order quantities, quality and delivery.

Box 4

\section{Responding to changing export markets: The Ludhiana (India) woollen knitwear cluster}

Following the collapse of the Soviet market, the woollen knitwear industry was forced to not only seek new markets in order to rebuild its production, employment and earnings, but it had to do so with fewer funds from the Government, and in a policy environment that exposed it far more sharply to the fluctuations of global competition. How would Ludhiana's knitwear exporters be expected to react to the crisis that they faced? From the debates in the literature on global commodity chains and the "new competition", which document the difficulties faced by labour-intensive firms in moving into more demanding international markets, the region would have been expected to go through a slow and painful adjustment phase, particularly because its economy was so tied to the woollen knitwear industry. Contrary to these expectations, the region's knitwear industry recovered unexpectedly rapidly. For one year, the knitwear sector suffered substantial cutbacks in demand. But after only a year's disruption, the cluster surged back with a 42 per cent increase in woollen knitwear exports in 1992-93. Output not only rebounded, but overseas exports grew at a much faster rate (nearly seven times faster) after the crisis, compared to the pre-reform period. This growth, moreover, was accompanied by a decisive shift in the direction of exports: increasingly away from the former Soviet Bloc and towards the more demanding European and North American markets.

Source: $\quad$ Tewari. 1999:1653-54.

Tewari provides three reasons to explain why the cluster was able shift rapidly to Western export markets:

\footnotetext{
${ }^{11}$ This account is based on Tewari (1999).
} 
- Firms had developed expertise in design, fashion changes, consistency of quality and brand building by supplying high-end segments of the domestic market, even while supplying low-end exports to the Soviet market. These capabilities were crucial for moving into the new export markets.

- The firms invested in "hiring designers, skilled workers, upgrading their finishing, packaging distribution systems" (Tewari, 1999: 1654).

- Within the cluster, there had been a group of medium-sized enterprises that had exported to Western Europe even during the 1970s and 1980s. In many cases, these firms built up relationships with medium-sized overseas partners. More generally, foreign buyers, and in particular small foreign buyers, played a crucial role as intermediaries linking into the cluster's supply system (Tewari, 1999:1660).

This case highlights, firstly, the ways in which firms can participate in multiple markets and attempt to transfer the lessons of one market to another. Secondly, it emphasizes the diversity of global buyers and the differences between the large buyers described by Schmitz in the case of the Sinos Valley and the smaller buyers who worked with the medium-sized exporting firms in Ludhiana. Thirdly, it should be noted that the response of the Ludhiana cluster also depended on firm-level reorganization and investment, and this investment was as much in design, skills and reorganization as it was in new equipment.

These findings are supported by recent work on the Sinos Valley shoe cluster in Brazil by Bazan and Navas-Alemán. ${ }^{12}$ The challenge facing the biggest exporters in the cluster due to the increased penetration of Chinese footwear into the North American market has been outlined above. The research carried out by Bazan and Navas-Alemán has highlighted the role of the domestic, and particularly the regional Latin American market, in developing capabilities in the cluster. For parts of the Latin American market, the Brazilian producers design products and market them through predominantly arm's length market relationships. In these market-based chains, producers incorporate most of the essential activities from design to marketing (the latter often through their own sales representatives). The opportunities for learning offered by smaller buyers might allow the development of capabilities that could be applied to larger export customers, as well as acting as a showcase for exporters.

These examples illustrate that in more mature product areas the gap between the requirements of the domestic market and global markets may not be as large as suggested by Hobday and by Keesing and Lall (see Section 3 above). If the gap is more in quality and standards, then it might effectively be bridged by learning from buyers in assembly and original equipment manufacture (OEM) relations.

\subsection{Building on buyer linkages: Upgrading in Taiwan, China}

Firm-level strategies of learning from working within particular value chains and then developing and applying this knowledge as part of an upgrading strategy have been

\footnotetext{
12 This account is based on Bazan and Navas-Alemán (2001) and Navas-Alemán and Bazan (2003). See also the papers in Schmitz (2004).
} 
discussed in an analysis of contract manufacturers in Taiwan (China) by Lee and Chen (2000). They show how a capability strategy has to be linked to a marketing strategy.

The argument advanced by Lee and Chen is that, in order to upgrade, firms not only have to develop new competences, but also have to apply these competences in ways that do not endanger existing value chain relationships. Buyers are wary of potential competition from outsourcing partners and may therefore "tend to be cautious in transferring design and development technology" (2000: 4). Upgrading therefore involves two types of firm-level strategy. Firstly, competences have to be built up. The analysis offered by Lee and Chen emphasizes the investment in human material resources required to make learning possible. Like Hobday, they are inclined to see technological learning as "a dynamic, difficult and costly process" (Hobday, 1995: 33). Secondly, the ability to make new products has to be complemented by product development and marketing strategies that do not directly challenge important customers. The continuing commitment of these customers is important for production scale and predictability of sales. Therefore, when contract manufacturers develop new products of their own, they might focus on low-end products that do not compete directly with those of major customers, and they may also direct them towards smaller markets which are less important for their customers.

\title{
4.5 The role of trade policy
}

This overview of the issues of global buyers, access to markets and upgrading, undertaken largely from the firm and value chain perspectives, should not ignore the importance of trade policy. Particular attention needs to be paid to the role of trade policy in preventing upgrading by firms in developing countries. Some preferential trade agreements actively discourage upgrading because of their restrictive conditions with respect to local content. In analysing the development of the Caribbean textile industry in the context of United States trade preferences, Mortimore observes that:

\begin{abstract}
[...] special access [to the United States market] represents a direct challenge to the national industrialization process. The HTS 9802 mechanism penalises practically all value added outside the United States (...) It is extremely difficult for the national government of the assembling country to implement policies that effectively promote further local integration of the industry (...) Thus the HTS 9802 mechanism tends to truncate the industrialization process itself, isolating the assembly operation in the Caribbean Basin to the detriment of any integrated national industrialization process in the assembly country. (Mortimore, 2002: 299)
\end{abstract}

More generally, Kaplinsky (1993) has argued that this type of trade policy is trapping Caribbean countries in low-wage activities and into a cycle of low-road competition characterized by declining wages and competitive devaluations.

Not all preferential trade policies have this effect. The North American Free Trade Agreement (NAFTA) has opened up new opportunities for Mexican producers that are much more attractive than the previous maquila system (Bair and Gereffi, 1998). Perhaps more interestingly, the United States African Growth and Opportunity Act 2000 (AGOA) provides for two options for inputs, namely from the United States or from within 
qualifying countries in Africa. ${ }^{13}$ AGOA appears to have interacted with the increasing importance of East Asian companies in global sourcing and the supply of textiles and apparel to stimulate AGOA-related FDI from East Asian companies in Africa. This is seen clearly in Figure 4, which shows leading investments in the apparel and textile industries. Companies from a range of East Asian countries have invested in textile and apparel production, and factories have been developed rapidly in response to AGOA in countries such as Lesotho. In many cases, leading East Asian garment companies supply the designs, fabric and materials, and they may also operate the garment factories themselves. East Asian expertise has facilitated a rapid supply response in Africa to AGOA preferences.

\section{Figure 4 AGOA-related investments in the textile and apparel industries of sub-Saharan Africa}

\begin{tabular}{|c|c|}
\hline Country & Investment \\
\hline Côte d'Ivoire & Investment by Henan Yuboa Textile (China) in textile factory. \\
\hline Lesotho & $\begin{array}{l}\text { Increase in textile employment from } 17,000 \text { in } 1999 \text { to } 40,000 \text { in January 2002, mostly as a result of } \\
\text { investment by Asian companies. } \\
\text { Nien Hsing (Taiwan, China) opens garment factory. } \\
\text { Investors from Taiwan (China) announce investments of } \$ 100 \text { million in the textile industry. } \\
\text { Between } 1995 \text { and } 2001 \text { investors from Taiwan (China) include China Garment Manufacturers, Nien } \\
\text { Hsing, Carry Wealth Group and Precious Garments. } \\
\text { Firms from Taiwan (China) estimated to employ more than half of all workers in the sector (Gibbon, } \\
\text { 2002: } 21 \text {-22). }\end{array}$ \\
\hline Mauritius & $\begin{array}{l}\text { Mast Industries, the GAP, Eddie Bauer (all United States) and William E. Connor Associates (Hong } \\
\text { Kong, China) open buying offices as a result of AGOA. } \\
\text { Shenxi (China) building spinning mill. }\end{array}$ \\
\hline Namibia & Ramatext Textiles (Malaysia) constructing an integrated textile and clothing plant. \\
\hline Rwanda & Competent Group (Hong Kong, China) plans to invest in a garment manufacturing plant. \\
\hline South Africa & $\begin{array}{l}\text { Many AGOA-related investments in the textile, clothing and automotive industries. Ramatext Textiles } \\
\text { (Malaysia) investing in a textile mill and export garment factory }\end{array}$ \\
\hline Swaziland & $\begin{array}{l}\text { Nam Woel Industrial (Taiwan, China) investing in new sewing machines. } \\
\text { Nien Hsing Textile opens denim plant in Swaziland. } \\
\text { Tex-Ray (Taiwan, China) invests in factory expansion }\end{array}$ \\
\hline Uganda & $\begin{array}{l}\text { OTK (South Africa) buys cotton ginning plant to supply AGOA-compliant raw materials for South } \\
\text { African cotton spinners. }\end{array}$ \\
\hline \multicolumn{2}{|c|}{ Source: United States International Trade Commission (2002), except where otherwise indicated. } \\
\hline
\end{tabular}

\section{Upgrading within chains: Making the chain more sophisticated}

The strategies discussed in the previous section involve finding new buyers. However, in some industries there are opportunities for upgrading in cooperation with existing buyers. One particularly important pattern of upgrading has been termed "industry co-evolution" or "supplier co-evolution" by Sturgeon and Lee (2001). This is the process by which value

13 The least developed countries that qualify for AGOA are allowed to use materials imported from any part of the world until 2004. After that date, textiles, thread, etc. will have to be sourced from within Africa or from the United States. More information about AGOA can be found at http://www.agoa.gov. An analysis of how AGOA changes terms of access to the United States market for sub-Sahara African countries can be found in UNCTAD (2003). 
chains are upgraded and repositioned as the sector both restructures and comes to provide more sophisticated products. ${ }^{14}$ Two examples of this process are described here. The first is taken from Sturgeon and Lee's analysis of contract manufacturing in the electronics industry. The second is taken from export horticulture.

\title{
5.1 Industry co-evolution in the electronics sector
}

One of the features of the global electronics industry in the past decade has been the increasing use of outsourcing. This has been mainly analysed from the point view of the increasing importance of design and branding for global companies such as Nokia and Apple. However, the same process has consequences for upgrading possibilities in the rest of the value chain:

\begin{abstract}
While it has been widely noted that widespread outsourcing results in the emergence of a deverticalized industrial landscape (...), little attention has been paid to the evolution of the supply-base that has arisen to supply newly deverticalized lead firms. This lacuna has led to the erroneous characterization of the deverticalization process as one where industries are evolving toward smaller, highly specialized firms, each of which has shed its 'non-core' activities to focus on a few 'core' competencies. The deverticalization trend looks very different from the supplier's perspective. To meet the growing demand for full-service, or 'turn-key' outsourcing solutions (...), suppliers have in many cases had to add entirely new competence areas, increasing their scope of activities while improving quality, delivery, and cost performance. Increased outsourcing has also, in many instances, vastly increased the scale of suppliers' operations. Thus, increased outsourcing has led to a deepening of competence and an increase in scale at supplier firms. As supply-bases come to be comprised of large, highly capable suppliers the prospects for increased outsourcing are improved. In this way, suppliers and lead firms co-evolve in a recursive cycle of outsourcing increasing supply-base capability and scale (...). (Sturgeon and Lee, 2001: 4)
\end{abstract}

Over a period of time, contract manufacturers in the electronics industry have moved from being simple assemblers, putting together components supplied by their customers and to their specifications, to providing a broad range of services, including logistics, component purchasing and design adaptations. In the case of the large American contract manufacturers, they now provide worldwide assembly services. Contract manufacturers in Taiwan (China) provide more complex services, ${ }^{15}$ including some original design manufacture. In both cases, the suppliers have evolved with the industry itself.

\footnotetext{
14 The term "product" is used here to denote not only the physical product, but the set of services and attributes that are bundled with it.

${ }^{15}$ This issue is discussed in section 6.2.
} 


\section{2 "Growing up with the sector": The acquisition of capabilities by suppliers in the African horticulture industry}

Another case of the co-evolution of firms along the value chain can be seen in the horticulture industry, described above in Box $1 .^{16}$ In the late 1960 s, wholesale markets traded 90 per cent of fresh horticultural produce in the United Kingdom, linking dispersed producers with small retailers, greengrocers and market stalls. When Kenya began selling "Asian" vegetables and off-season temperate vegetables in the United Kingdom during the early 1970s, these too were sold through wholesale markets. Barriers to entry for both exporters and producers were low.

When United Kingdom supermarkets first entered the fresh vegetable trade, they purchased products from the wholesale market, employing wholesale agents working on a commission basis. This meant that they had little or no information about the precise origin of products and could exercise only limited control over how products were produced. Similarly, the use of wholesale markets provided the supermarkets with little control over the type or quality of product and greatly restricted their capacity for production scheduling and season planning.

By the mid-1990s, United Kingdom supermarkets had restructured the business so that it could serve their needs through: firstly, product differentiation and innovation; and secondly, the control risk in the face of a more complex regulatory and consumer environment. Fresh produce was profitable, and it was one of the few products that determined the choice of stores by consumers. The supermarkets extended the range of imported produce on offer by introducing new vegetables, more sophisticated packaging and increased levels of post-harvest processing, such as washing, trimming and chopping.

It was also important for these products to be supplied consistently over the year, even if this meant sourcing produce from different countries around the world. The value chain was not only expected to supply a physical product, but also a range of services associated with it, such as consistency, reliability of delivery and the capacity to innovate.

In the course of meeting these challenges, locally-owned producers and exporters in Kenya experienced considerable upgrading in the following areas:

- Introduction of more complex logistics and management of the "cool chain" to improve the quality of the product and its shelf life.

- Greatly increased local processing, including trimming, chopping, packaging in a variety of formats, labelling and bar-coding.

- Responsibility for innovation, including conducting trials of new products and new varieties which, for example, involves working with seed companies. There has been a significant expansion of the range of products supplied by Kenyan exporters.

- Innovation to meet increased regulatory requirements, such as the development of integrated crop and pest management systems in response to European Union

${ }^{16}$ This section is based on Dolan and Humphrey (2000 and 2001). 
legislation on minimum residue levels for pesticides. Similarly, exporters have had to respond to increase demands for product traceability along the value chain and compliance with sectoral standards for environmental and labour practices. ${ }^{17}$

- Investment in facilities such as irrigation and lighting, as well as "high-care" facilities capable of meeting European Union regulations for the preparation of ready-to-eat products.

Exporters of fresh vegetables from Kenya are now much more sophisticated and have a much wider range of value chain functions than was the case 20 years ago. In some cases, this reflects the increasing sophistication of the final product and the introduction of new capabilities into the value chain. In others, it reflects the transfer of activities from United Kingdom importers to Kenyan exporters, as the former focus more on global logistics and supply chain management and less on trading and processing.

Upgrading has occurred, but with consequences for the structure of the chain and the barriers to entry in the sector. Firstly, there has been a concentration of firms in the export horticulture business. In fresh vegetables, in particular, fewer and fewer firms are responsible for most exports from Kenya to northern Europe. Secondly, there has been a concentration of production, with the large exporters bringing a greater proportion of production in-house and reducing their reliance on smallholder production. Thirdly, barriers to entry have increased. New entrants to the sector have to start large rather than become large by evolving with the sector.

\subsection{Upgrading strategies for latecomer firms}

As suppliers gain competence, new functions become more widespread and are established as the norm for the industry. They become an entry requirement. The entry barriers for latecomer firms in the global economy therefore rise. Section 5.2 described how, for example, Kenyan exporters of fresh vegetables acquired a range of skills in the production, processing and export of vegetables.

These challenges are particularly problematic for small firms, smallholders and the informal sector. The requirements of the value chain in terms of traceability, managerial systems and scale make it difficult for these firms to participate. There are certain subcontracting roles available to them, but if the requirements placed on producers at early stages in the value chain rise, one response is for production to be brought in-house. This has been seen in the increasing use of own-farm production by Kenyan fresh vegetable exporters.

This exclusionary tendency is driven by the increasing emphasis on standards, codes and labels. The more lead firms in the value chain are held responsible for events further back along the chain, the more they monitor activities and enforce standards along the chain. There are economies of scale in monitoring and enforcing standards, and lead firms may

${ }^{17}$ The response of the sector to legislation on minimum residue levels for pesticides established by the European Union involved both direct buyer-supplier value chain collaboration and collective efforts within and between the export sector in Kenya and European importers and buyers. 
try to reduce the number of points of control required in the chain by reducing the number of firms at different points along the chain.

The global regulatory environment is becoming more complex as a result of responses to concerns about consumer safety, the environment and labour standards. ${ }^{18}$ An example of what this implies for producers in developing countries is presented in Box 5. In this case, a developing country leather garment manufacturer was faced with meeting not only the challenge of being competitive in the production of leather garments, but also of ensuring that its leather supplies were produced in accordance with European Union environmental regulations.

\section{Box 5}

\section{Supply chain implications of meeting European Union environmental requirements for leather garments}

One Ethiopian producer of leather garments we met recently told us that to expand exports he would need access to leather conforming to European Union environmental regulations. At the moment he could only win "spot" or top-up orders from international buyers and occasionally some European fashion garment retailers. As a marginal supplier, his products escaped too much scrutiny. However, to become a regular supplier, he would have to ensure that the leather used for his garments was processed in an environmentally-acceptable manner, as defined by the European Union and the retailers he was supplying. He did not believe that such environmentally-acceptable leather was available locally.

Source: author interview.

How could the leather garment exporter face this challenge? One option might be to import the required leather, but this has three disadvantages. Firstly, the competitive advantage that the garment manufacturer gains from the use of local leather supplies would be lost. Secondly, the disadvantages that local producers may face as a result of poor transport infrastructure and trade bureaucracy would be magnified by the use of imported inputs. Thirdly, the benefits to the Ethiopian economy would be diminished by the use of imported inputs. A second option might be to integrate backwards and move into tanning, but this might well be a distraction from the efforts needed to become a competitive garment manufacturer. ${ }^{19}$

More effective from the national development perspective might be efforts to upgrade the tanning industry. In the case of Ethiopia, such efforts are described by Bini (2002). These efforts have involved not only government support for individual enterprises and the promotion of greater linkages between agents (both horizontally and vertically) at various stages in the tanning industry, but also the mobilization of international resources through Africa-wide networking and the support of institutions such as UNIDO. In the environmental area in particular, Bini notes the role played by UNIDO in the development

${ }^{18}$ An overview of standards and the issues they raise for value chain analysis can be found in Nadvi and Wältring (2002). The impact of global standards on furniture producers in South Africa is discussed by Kaplinsky et al. (2002).

19 The lack of suitable suppliers has often been the reason for developing country firms and industrial pioneers in many countries to be highly vertically integrated. However, such integration frequently imposes cost penalties that cannot be sustained in competitive markets. 
of effluent treatment plants and testing laboratories. These are required to test both the waste produced by the tanning process and the leather products themselves.

Similar challenges have been highlighted in a study by Tewari and Pillai (forthcoming) on the leather industry in Tamil Nadu. Meeting challenges relating not only to effluent treatment and pollution, but also a ban imposed by the German government on leather containing PCPs and Azo dyes, required significant local organization involving firms, institutions and government at the regional and national levels. Solutions included national bans on certain types of chemicals, investment in treatment plants and the development of local testing facilities.

As the entry requirements for global markets are tending to increase as a result of both changing demands by global buyers and the increasing complexity of the regulatory environment, local and national policy becomes more important in facilitating the entry and upgrading of developing country firms. Policy interventions can be found in the following areas:

- Local and national initiatives (sometimes in conjunction with international agencies) aimed at improving the capabilities of particular sectors and industries so that they can meet the requirements of international markets. These requirements may include compliance with standards (and proof of such compliance), as well as investment in basic infrastructure to meet logistical requirements. In many cases, these investments cannot be made at the enterprise level and require collective action.

- Where entry requirements to particular markets are considerably beyond local capabilities, support agencies may be able to find less demanding customers. These may include markets that are less sophisticated in terms of product or regulatory requirements, or different types of buyers. In the case of the horticulture industry, for example, alternatives to large retailing chains in northern Europe might include customers in Middle Eastern and East European markets, or traders supplying the catering market.

- Given the increasing complexity of global standards for both products and processes, business organizations ${ }^{20}$ and governments in developing countries should work towards simplifying the global standards system, not by reducing requirements, but by avoiding overlapping standards and the duplication of standards. Overlapping or duplicated standards are seen clearly in the horticulture industry in Kenya, for example. Flower production is subject to regulation by the local Kenya Flower Council certification scheme, the EUREP Good Agricultural Practice (GAP) system, the United Kingdom's Ethical Trading Initiative, the Flower Label Programme and the Dutch Milieu Programme Sierteelt (MPS) scheme for flowers. ${ }^{21}$ The overlapping and duplication of standards also emerges as a significant problem for SME component manufacturers in the Brazilian auto industry (Quadros, 2002).

\footnotetext{
${ }^{20}$ The way in which inter-firm cooperation is required for upgrading in situations in which the improvement of products requires simultaneous action at various points in the value chain is discussed by Morris (2001).

${ }^{21}$ This information comes from a leading Kenyan flower exporter.
} 


\title{
6. The formation of global supply networks
}

The upgrading strategy for manufacturing based on the East Asian model developed by Wortzel and Wortzel (1981) and described in Section 3 is based largely on the premise that firms in advanced countries seek out suppliers in developing countries and work with them where necessary to improve supplier capabilities. These firms are often leading global manufacturers looking to outsource production to low-cost locations. Even if they outsource to multiple locations, they work with the suppliers in each location.

This model of export-based upgrading offers two paths to firms that are integrated into the global economy. On the one hand, they can provide a greater range of capabilities embedded in products sold to their initial customers. On the other hand, as they become more skilled at original equipment manufacturing and also incorporate some basic design functions, they are able to supply companies that have fewer manufacturing skills of their own, such as retailers or brand-name companies. In both cases, however, single plant firms in developing countries are able to meet the needs of export customers.

In the course of the 1990s, a new pattern of global sourcing emerged in some industries. The buyers themselves became more global, supplying products to a greater range of markets and looking increasingly for global suppliers (Sturgeon and Lester, 2001).

Supplying global products to many markets around the world often requires firms to make these products in various locations. There are two main reasons for this. Firstly, production may need to be sited close to final markets because of transport costs or the need to respond rapidly to changing market conditions. An example of the impact of geographical proximity to markets is shown in Box 6 . Secondly, trade barriers may force companies to locate production in various sites. National or regional local content requirements and quota restrictions (particularly important in garments) lead to globally fragmented value chains.

Box 6

Delivery time and being close to the market: Clothing

\begin{abstract}
All the traditional industries, but especially clothing, are sensitive to fashion. This gives Mexico a particular advantage, relative to other low-wage developing countries, of proximity to the United States market. The magnitude of that advantage is suggested by one brand name retailer who reported that shipment from Mexico to its Texas warehouse took four days, compared to 30 days from the Republic of Korea. Another brand name retailer, a United States shoe company, estimated total time to market, from initial order to receipt of the finished goods, at seven to eleven weeks in Mexico compared to 14 to 15 weeks in Hungary or Italy, 18 in Portugal and 23 to 25 weeks in Brazil, China or Indonesia.
\end{abstract}

Source: Dussel Peters et al. (2002: 231)

The consequence of this has been the emergence of global suppliers working with global buyers through the formation of globally-dispersed supply networks. This change is the dynamic dimension of buyer-supplier upgrading, as illustrated by two cases: the automotive industry and the electronics industry. 


\subsection{Global first-tier suppliers in the auto industry $^{22}$}

Governments in developing countries have promoted the local assembly and production of components in the auto industry in order to generate employment, develop technological capabilities through spillovers into local industry and reduce the foreign exchange cost of imported vehicles and components. Local content requirements, in particular, have been used to create local supply industries.

For example, the Brazilian automotive industry was created in the 1950s, when the government put the auto industry at the centre of its strategy for rapid industrial development and modernization. A virtual ban on vehicle imports, combined with incentives for companies to begin local production, created a domestic auto industry with a high level of local content. A local components industry grew up, using licensing agreements and in some cases equity partnerships. This industry developed its technological capabilities as it met the demand for the adaptation of vehicle designs to the needs of the local market.

The inefficiencies of this model of import substitution industrialization are well known. However, this development strategy did create some Brazilian-owned globally competitive automotive component suppliers. By the early 1990s, the leading Brazilian-owned component manufacturers were exporting to North America and Europe and beginning to set up plants and research and development facilities in these markets. However, this development has been cut short by the growth of global first-tier suppliers in the auto industry. This has arisen as a result of three tendencies:

- The increasing role given to first-tier suppliers in the design and supply of components, modules and systems.

- The reduction in the gap between advanced country and developing country vehicle models following trade liberalization in the 1990s.

- The adoption of strategies of follow design (using as far as possible the same design in multiple locations) and follow sourcing (using as far as possible the same supplier in a multiplicity of locations) as a means of reducing the costs of producing vehicles in many different countries and increasing the speed of introduction of new vehicles.

Leading global auto assemblers increasingly look for global first-tier suppliers which can provide components in multiple locations around the world. The rapid internationalization and consolidation of the auto components sector has been widely discussed (Sadler, 1999; Sturgeon and Florida, 1999). The impact of these changes on firms in developing countries has been less widely noted, but has been substantial. Studies of the auto industry in a number of developing countries have shown how locally-owned firms have been marginalized by the globalization of first-tier automotive supply. This problem is not confined to Brazil. It has been observed in South Africa by Barnes and Kaplinsky (2000), in Brazil and India by Humphrey and Salerno (2000) and in Poland by Balcet and Enrietti (1997). It was also seen in Spain when that country's motor industry was integrated into a wider European division of labour (Aller et al., 1999). The issue is most likely to arise in situations where the same vehicle is being manufactured in various countries. It is

\footnotetext{
${ }^{22}$ This section is based on Humphrey (2000) and Humphrey and Memedovic (2003).
} 
therefore less likely to happen where production of speciality vehicles (for example, the new VW Beetle or the Chrysler PT Cruiser) is concentrated in one location, or where cars are still built solely for the domestic or regional market.

The extent of the problem can be highlighted by the case of the components industry in Brazil. The results are summarized in Box 7, which shows the extent of the denationalization of the industry in the late 1990s, and in Box 8, which describes the case of one leading Brazilian component manufacturer, Freios Varga. These Brazilian first-tier suppliers were unable to offer global sourcing for their customers. They could not supply parts, for example, in Eastern Europe, India, Thailand or South Africa, from factories located in these countries. As a result, they were swept up in the global consolidation of the components industry.

\section{Box 7}

\section{Globalization and denationalization of the Brazilian automotive components industry}

In 1995, the 25 largest component companies (excluding tyre manufacturers) by turnover were split evenly between Brazilian-owned companies and transnational companies: 12 were Brazilian, 12 transnational and one was a joint venture. This pattern of ownership in the auto industry had remained roughly similar for at least the preceding 15 years. The 1980 listing of firms in the Brazilian components industry produced by the business magazine Visão showed that eight of the 20 largest component companies were already foreignowned.

The ownership pattern changed dramatically in the second half of the 1990s following trade liberalization, major new investments by global assemblers in Brazil and the updating of Brazilian model ranges. By 2001, eight of the 12 largest Brazilian-owned component manufacturers in 1995 had been sold to transnational companies and one had become a joint venture. The three remaining Brazilian-owned companies from the top 25 (in 1995) all produced components for the heavy vehicle market.

Source: Figures based on Quadros et al. (2000). Further research by the author and information provided by Dr. Ruy Quadros of the University of Campinas in Brazil.

\section{Box 8}

\section{The rise and decline of Freios Varga}

The story of one leading Brazilian component manufacturer, Freios Varga, illustrates the development cycle of the Brazilian auto components manufacturing industry as a whole. The company started producing brake parts for the replacement market in the 1950s, copying parts supplied by other companies to the domestic market. At this time, import restrictions allowed many locally-owned companies to enter the market for replacement parts. At the end of the 1950s, Freios Varga began original equipment production, working to designs supplied by Volkswagen.

In 1971, it negotiated a technology tie-up with Lucas, which took a minority stake in the company. Varga began to design new products to meet the needs of assemblers as they introduced models targeted specifically at the Brazilian market, such as the Ford Corcel II and the VW Gol. The company relied on Lucas for basic technology, but retained its own engineering capability in order to adapt designs to the local market and develop brakes for locally-designed models. Lucas held only a 34 per cent stake in the Brazilian company. The joint venture was a success. Not only did it enjoy a dominant position within the domestic market, but following the general trend for increased export orientation in the 1970s and 1980s, it managed to export increasing amounts of its production to the North American market. By the mid-1990s, it had received many prestigious quality awards from the big three North American assemblers, including GM's Supplier of the Year award. The tie-up with Lucas was very successful. However, when Lucas merged with Varity Corporation, Freios Varga was competing in the North American market directly (and successfully) against plants owned by Varity. As a result, Lucas-Varity bought the remaining 66 per cent of shares in Freios Varga. The family that had built up the company over more than 40 years relinquished its control.

Source: Humphrey and Memedovic (2003: 43). 
This has serious consequences for developing country firms. If this tendency towards global sourcing continues, or is extended to other industries, then locally-owned companies in developing countries will face serious disadvantages. They will find it difficult to become first-tier suppliers to multinationals operating in their domestic markets and they may find that opportunities to export to industrialized countries will also depend upon providing "global supply solutions".

\subsection{Beyond the auto industry}

How general is this problem? The pitfalls of generalizing from the experience of the auto industry are well known. The industry is economically important and highly visible, but it has many features that are specific to it alone. There are nevertheless grounds for thinking that a more general trend is evident in the global economy.

In the electronics industry, there are clear signs that contract manufacturing is becoming more global, with leading contract manufacturers, such as Solectron and Celestica, providing a global footprint for their customers (Sturgeon and Lester, 2001). So, for example, if a global brand-name firm wants its products assembled in Eastern Europe, either for geographical convenience (build and configure to order, rapid response), or because of preferential trade access to European markets, it then expects the contract manufacturer to provide a manufacturing base.

A new breed of global supplier has also emerged in the garment industry. In some cases, these firms are predominantly (although not exclusively) traders which match orders from buyers with production facilities in many different countries. For example, the well-known garment company, Li \& Fung, has 60 offices in 36 countries and is able to provide its customers with many different products and production locations (Sturgeon and Lester, 2001: 48-49). Similar firms, also based in East Asia, have more of their production capacity in-house. They are global producers and traders.

In sectors such as garments, in which trade preferences still play an important role because of quotas and because of the impact of tariffs on cost-sensitive product ranges, these global companies play an important role in distributing global production in a way that maximizes the benefit of trade preferences. This appears to be one of the reasons for the rapid African supplier response in the garments sector to the opportunities opened up by the African Growth and Opportunity Act (AGOA), described in Section 4.5.

\subsection{Consequences of the globalization of supply chains}

The development of global sourcing strategies and global supplier networks has four clear consequences for access and upgrading for developing country enterprises.

Firstly, to the extent that qualification as a first-tier supplier in some industries now appears to depend upon being able to produce and supply in multiple locations, the entry 
barrier for developing country firms has risen. Nevertheless, more research is required to understand the factors that lead to the formation of such networks. They will not arise in all industries, and the form they take will vary from sector to sector.

Secondly, the formation of these networks has led to the creation of new global companies. In the case of the automotive industry, these new global firms are first-tier manufacturers which have considerable design and technology capabilities. In the case of the garments industry, the core competences of the new global firms appear to be more located in logistics skills and the translation of design ideas into detailed product specifications, although the balance between firms that are predominantly traders and firms that are also transnational producers may be changing. Recognition of the roles played by different types of global buyers and consideration of their impact on value chain configuration and coordination is one of the key insights of global value chain analysis.

Thirdly, these new intermediaries will have an impact on upgrading paths for developing country enterprises. It was suggested in Section 4 that the receptivity of global buyers to upgrading efforts by their suppliers would depend on the extent to which such efforts encroach (or do not encroach) on the buyers' core competences. In the case of global intermediaries themselves, it seems clear that their increasing role in logistics and design has been welcomed by retailers and brand-name companies whose core competences lie in branding and marketing. The cases of value chain co-evolution described in Section 5 also demonstrate that buyers may welcome increasing supply competences as part of a broader strategy of focusing on their own core competences.

But what are the core competences of these new global sourcing companies, and how might they affect the upgrading opportunities of developing country enterprises? Once again, this depends on the sector and the roles performed by the global sourcing companies. However, it seems likely that when these global sourcing companies are predominantly traders, with logistics and trading expertise, and with good knowledge of where to source different products, their continued dominance within the value chain is probably strengthened by maintaining distance between suppliers and customers and by limiting the suppliers to a narrow range of production functions. This will lock developing country firms into assembly tasks.

Finally, it seems likely that the emergence of these globalized sourcing companies increases the speed of response to changing preferential trade agreements. Companies that specialize in logistics and sourcing are able to respond to changing trade preferences very rapidly by relocating production. This means that the immediate employment and production effect of trade policy is more rapid, but the development impact is shallow, while long-term upgrading possibilities are more restricted. What should countries such as Lesotho do to sustain the AGOA-related garment industry? In particular, how could it ensure that the industry survives a possible phasing out of the AGOA preferences? This strategic question has also exercised the minds of policy-makers in relation to the garments industry in Bangladesh.

This means that the developmental impact of preferential trade policies varies considerably according to their detailed specifications on issues such as local content and rules of origin. With many preferential trade schemes being introduced or re-negotiated, an assessment of their developmental impact in the context of new patterns of globalization is essential. 


\section{Value chain strategies for global markets}

What does the analysis of globalization and global value chains that has been developed so far imply for policies aimed at upgrading agricultural and manufacturing capabilities in developing countries? It reinforces five basic points:

(a) Learning and the acquisition of technological capabilities can be stimulated through involvement in global value chains. However, there is no guaranteed path to upgrading as a result of this involvement.

(b) Upgrading involves the development of both technological capability and market access. Complementary efforts at the local and national levels are needed to stimulate both.

(c) Learning is not costless. It has to be active and purposive, and it requires investment by firms and support agencies. Insertion into global value chains provides opportunities for learning, but these have to be acted upon. One of the most important lessons of the East Asian experience is that firms and enterprise development policies must consider integration into global markets as a learning opportunity that has to be maximized through explicit effort and investment by the firms concerned, supported by public and public-private agencies. "Learning by exporting" or "learning by doing" is not enough. Investment in upgrading is likely to suffer from the market failures identified by Lall (2001), which supports the case for State intervention.

(d) Upgrading has been possible, not only in East Asia, but also in a variety of developing countries. Nevertheless, new global value chain configurations are making previous upgrading strategies more difficult. Upgrading strategies have to be adapted to the changing nature of global value chains.

(e) The "East Asian" ideal model of moving from assembly through original equipment manufacture $(\mathrm{OEM})$ and original design manufacture (ODM) into original brand manufacture (OBM) is not the only model. Even in East Asia, leading firms have found it difficult to make the transition to OBM. It is both costly and risky.

Policies to stimulate and support the upgrading efforts of firms and groups of firms can be divided into three types: (i) policies that support upgrading irrespective of the specific nature of global value chains; (ii) policies that facilitate the participation of firms in globally dispersed production systems; and (iii) policies that support firm level upgrading in the context of the specific challenges and opportunities opened up by contemporary value chain linkages in the global economy.

The continuing importance of basic policies to support upgrading has been highlighted by Sturgeon and Lester (2001), who emphasize the continued importance of stability for firms to make investments in capital equipment, learning and technological capability:

(a) Given that learning is not costless, macroeconomic stability and a predictable future environment is an important factor in firm level investment decisions, although it should be noted that export-oriented investments are insulated from exchange rate instability because they generate earnings in foreign currency.

(b) Credit at affordable rates of interest is also important for firm level investment. Otherwise, firms are restricted to investments that can be financed out of profits. 
(c) Education remains a priority, both in terms of basic education for the workers employed in export-oriented factories and the education of the engineers and technical staff that are needed at all stages of the upgrading process, and in particular for the transition to original design manufacture (ODM).

(d) The process of insertion into global markets is one of moving closer to the global production frontier. Emphasis on learning and upgrading in value chains arises from a recognition of the problems of imperfect markets, uncertainty, the cumulative nature of investment decisions and path dependency (Lall, 2001: 9-10). These are particularly problematic for latecomer firms in the global economy because of their lack of knowledge of both technology and markets, as highlighted by Hobday (1995). It follows that under-investment is likely in upgrading efforts that are prolonged and risky. This reinforces the case for policies to deal with these market failures.

Global value chain analysis also points to specific policy areas that require attention. One set of policy questions arises from the recognition that in the global economy firms in developing countries often form just one part of an international division of labour. Policies to facilitate the integration and coordination of activities that cross national boundaries are therefore required:

(a) Transport infrastructure development. To the extent that global production and distribution systems become more integrated, the reliability and efficiency of transport infrastructure becomes more important. In particular, in explicitly coordinated value chains, buyers are dependent on a narrow range of suppliers and continuity of supply becomes increasingly important.

(b) Access to imported inputs. Firms in global value chains often specialize in just one part of the process, with the extreme case being firms that only assemble products. One consequence of this is that ease of access to imports becomes an essential part of export competitiveness. This ease of access involves not only low tariff or duty-free imports, but also the physical and bureaucratic infrastructure to enable goods to be imported quickly.

(c) Access to specialist foreign labour. If latecomer firms in the global economy need to upgrade, they may well require specialist skills to support the learning process. Work permit and visa regimes should not obstruct the employment of the specialist foreign workers necessary to support the learning process.

(d) Finally, governments should be particularly careful when negotiating trade policies, and in particular bilateral trade policies and preferential access to markets in developed countries, because of the ways in which these facilitate or obstruct upgrading. Particularly damaging to upgrading prospects are preferential access schemes that restrict local content, such as the maquila system in Mexico, the Caribbean Basin Initiative (and the various schemes known as 807, 9802 and 807A) and the European Union outward processing traffic (OPT) initiative. The AGOA scheme is different because of its emphasis on American or local content. Trade policy and access should be considered in the light of development priorities.

There are also policy issues which arise from the changing nature of global value chains and the global economy. The following policy areas need to be emphasized:

(a) Strategy formulation and support for enterprise development must link the issues of technological capability and market access. Policies to support the acquisition of technological capability by local firms must consider the relevance of these capabilities to an overall upgrading strategy that also takes into account market 
access. Conversely, the market access strategy must consider the capabilities required for that market.

(b) As entry barriers to global markets rise, action by governments, international agencies and the private sector is needed to enable firms to gain initial access to global markets. Policies, including those directed at improving enterprise-level capabilities, and institutional frameworks are needed that support compliance with global standards.

(c) The problem of "lock-in" to low value-added activities needs to be addressed through active support for firms searching for new markets and customers. There is a role for publicly funded agencies in this area.

(d) As part of the process of locating markets, more emphasis should be placed on the ability to diagnose value chain linkages and trade opportunities in capacity-building efforts. Capacity-building programmes aimed at increasing national trade capacities should focus on value chain linkages and the implications of these linkages for market access. It is now recognized that market access issues include two components: trade policy and competitiveness, or in other words the capacities of firms to take advantage of access opened up by trade policy changes (UNCTAD, 2002a). A global value chain perspective adds a third aspect to the analysis and diagnosis, namely consideration of market structures and differentiation. Different buyers have different requirements, which demand different capabilities from suppliers. Export promotion activities need to be able to analyse these differences.

(e) When considering market diversification, the potential offered by domestic and regional markets, particularly for consumer non-durable products, should not be underestimated. These markets present three potential advantages. Firstly, to the extent that retailing is less concentrated in developing countries, there are more opportunities for small firms to sell to small buyers. Secondly, the distance from the market, which works to the disadvantage of latecomer firms in the global economy, can work to the advantage of latecomer firms supplying markets to which they are closer than globalized competitors. Thirdly, small buyers are more likely to look for the "full package" solution to their supply needs, including design and logistics. This offers both a direct route for upgrading and a means of acquiring capabilities that can be applied to wider markets.

(f) The emphasis on locating smaller buyers also applies in global markets. Much research and many high-profile examples of globalization involve global retailing and brand name companies, such as Nike and The Gap. Analysis of the successful switch of woollen garment exporters in Ludhiana, as discussed in Section 4.3 above, highlights the role played by smaller buyers in international markets. Such small buyers should also be targeted by market diversification strategies.

(g) Finally, it has to be recognized that upgrading paths and potential differ according to sectors. In different sectors, the types of buyers vary and the points at which value chain activities can be fragmented between firms and countries differ. Policies therefore have to be designed to address the needs of specific sectors. The examples given in this report illustrate how varied the challenges are between different sectors and for industries at different levels of technological capability. 


\section{References}

Aller, R.A., Bilbao, J., Beldarrain, V.C., and Longás García, J.C. 1999. "New tendencies in inter-firm relations in the automotive industry and their impact on European periphery suppliers: Lessons from Spain”, in European Urban and Regional Studies. 6(3): 255-264.

Arndt, S. and Kierzkowski, H. (eds.). 2001a. Fragmentation: New production patterns in the world economy. Oxford University Press.

----. 2001b. "Introduction", in Arndt, S. and Kierzkowski, H. (eds.), Fragmentation: New production patterns in the world economy. Oxford University Press.

Bair, J. and Gereffi, G. 1998. Interfirm networks and regional divisions of labor: Employment and upgrading in the apparel commodity chain. Paper presented at the "International Workshop on Global Production and Local Jobs: New perspectives on enterprise networks, employment and local development policy". IILS, 9-10 March. Geneva, ILO.

----. 2001. "Local clusters in global chains: The causes and consequences of export dynamism in Torreon's blue jeans industry”, in World Development. 29(11): 1885-1903.

Balcet, G. and Enrietti, A. 1997. "Regionalisation and globalisation in Europe: The case of Fiat Auto Poland and its suppliers", in Actes du GERPISA. 20: 15-30.

Barnes, J. and Kaplinsky, R. 2000. "Globalisation and trade policy reform: Whither the automobile components sector in South Africa?", in Competition and Change. 4(2): 211-243.

Bazan, L. and Navas-Alemán, L. 2001. Comparing chain governance and upgrading patterns in the Sinos Valley. Paper presented at the "Workshop on Local Upgrading in Global Chains". Brighton, Institute of Development Studies.

Bazan, L. and Schmitz, H. 1997. Social capital and export growth: An industrial community in southern Brazil. IDS Discussion Paper 361. Brighton, Institute of Development Studies.

Bini, A. 2002. Upgrading in the leather value chain: The learning experience of Ethiopian tanneries. MPhil Thesis, University of Sussex, Institute of Development Studies.

Castley, R. 1997-98. "The Korean electronics industry: The Japanese role in its growth", in Asia Pacific Business Review. 4(2-3): 29-47.

Damiani, O. 2002. Small farmers and organic agriculture: Lessons learned from Latin America and the Caribbean. Rome, International Fund for Agricultural Development.

Dolan, C. and Humphrey, J. 2000. "Governance and trade in fresh vegetables: The impact of UK supermarkets on the African horticulture industry", in Journal of Development Studies. 37(2): 147-176.

----. 2001. Changing governance patterns in the trade in fresh vegetables between Africa and the United Kingdom. Brighton, Institute of Development Studies. (Available at http://www.gapresearch.org/production/IFAMSubmission.pdf - visited on 8 March 2004)

Dussel Peters, E., Ruiz Durán, C. and Piore, M. 2002. "Learning and the limits of foreign partners as teachers", in Gereffi, G., Spener, D. and Bair J. (eds.), Free trade and uneven development: The North American apparel industry after NAFTA. Philadelphia, Temple University Press.

EUREP. 2001. EUREPGAP Protocol for Fresh Fruit and Vegetables. (Available at http://www.eurep.org/)

Feenstra, R. 1998. "Integration of trade and disintegration of production in the global economy", in Journal of Economic Perspectives. 12(4): 31-50. 
Gereffi, G. 1994. "The organization of buyer-driven global commodity chains: How U.S. retailers shape overseas production networks", in Gereffi, G. and Korzeniewicz, M. (eds.), Commodity chains and global capitalism. Westport, Praeger.

---- 1999. "International trade and industrial upgrading in the apparel commodity chain", in Journal of International Economics. 48: 37-70.

Gereffi, G., Humphrey, J., Kaplinsky, R. and Sturgeon, T. 2001. "Introduction: Globalisation, value chains and development", in IDS Bulletin. 32(3): 1-8.

Gereffi, G., Humphrey, J. and Sturgeon, T. 2004. "The governance of global value chains: An analytic framework", in Review of International Political Economy, forthcoming.

Gereffi, G. and Korzeniewicz, M. (eds.). 1994. Commodity chains and global capitalism. Westport, Praeger

Gibbon, P. 2002. The African Growth and Opportunity Act and the global commodity chain for clothing. Copenhagen, Danish Institute for International Studies. (Available at http://www.ids.ac.uk/globalvaluechains/publications/Gibbon-agoa.pdf - visited on 12 January 2004).

Gourevitch, P., Bohn, R. and McKendrick, D. 2000. "Globalization of production: Insights from the hard disk drive industry”, in World Development. 28(2): 301-317.

Grunwald, J. and Flamm, K. 1985. The global factory: Foreign assembly in international trade. Washington DC, Brookings Institute.

Hamilton, G., Feenstra, R. and Petrovic, M. 2003. The emergence of demand-responsive economies: A reassessment of the 'Asian Miracle' (mimeo). Washington DC, University of Washington.

Henderson, J., Dicken, P., Hess, M., Coe, N. and Yeung, H.W.-C. 2002. "Global production networks and the analysis of economic development", in Review of International Political Economy. 9(3): 436-464.

Hobday, M. 1995. Innovation in East Asia: The challenge to Japan. Cheltenham, Edward Elgar.

----. 1997-98. "Latecomer catch-up strategies in electronics: Samsung in South Korea and ACER in Taiwan", in Asia Pacific Business Review. 4(2-3): 48-83.

Hummels, D., Rapoport, D. and Yi, K.-M. 1998. "Vertical specialization and the changing nature of world trade”, in Federal Reserve Bank of New York, Economic Policy Review. 4(2): 79-99.

Humphrey, J. 2000. "Assembler-supplier relations in the auto industry: Globalization and national development", in Competition and Change. 4(3): 245-271.

Humphrey, J. and Memedovic, O. 2003. The automotive industry value chain: What prospects for upgrading by developing countries? Vienna, UNIDO.

Humphrey, J. and Salerno, M. 2000. "Globalisation and assembler-supplier relations: Brazil and India", in Humphrey, J., Lecler, Y. and Salerno, M. (eds.), Global strategies and local realities: The auto industry in emerging markets. Basingstoke, Macmillan.

Humphrey, J. and Schmitz, H. 2002. "How does insertion in global value chains affect upgrading in industrial clusters?”, in Regional Studies. 36(9): 1017-1027.

Kaplinsky, R. 1993. "Export processing zones in the Dominican Republic: Transforming manufactures into commodities", in World Development. 22(3): 1851-1865.

Kaplinsky, R., Morris, M. and Readman, J. 2002. "The globalization of product markets and immiserizing growth: Lessons from the South African furniture industry", in World Development. 30(7): 1159-1177.

Keesing, D. and Lall, S. 1992. "Marketing manufactured exports from developing countries: Learning sequences and public support", in Helleiner G. (ed.), Trade policy, industrialization and development. Oxford University Press. 
Kogut, B. 1984. "Normative observations on the international value-added chain and strategic groups", in Journal of International Business Studies. 15(2): 151-167.

Lall, S. 2001. Competitiveness, technology and skills. Cheltenham, Elgar.

----. 2002. Globalisation and development: Perspectives for emerging nations. Paper presented at BNDES 50th Anniversary Seminar. Rio de Janeiro, 12 September.

Lee, J.-R. and Chen, J.-S. 2000. "Dynamic synergy creation with multiple business activities: Toward a competence-based growth model for contract manufacturers", in Sanchez, R. and Heene, A. (eds.), Theory development for competence-based management: Advances in applied business strategy. Stanford, JAI Press.

Lee, S.-H. and Song, H-K. 1994. "The Korean garment industry: From authoritarian patriarchism to industrial paternalism", in Bonacich, E., Cheng, L., Chinchilla, N., Hamilton, N. and Ong, P. (eds), Global production: The apparel industry in the Pacific Rim. Philadelphia, Temple University Press.

Lim, J.D, 1993. "Restructuring of the footwear industry and the industrial adjustment of the Pusan economy", in Environment and Planning. 26(4): 567-581.

Magaziner, I. and Patinkin, M. 1989. The silent war: Inside the global business battles shaping America's future. New York, Random House.

Morris, M. 2001. “Creating value-chain cooperation”, in IDS Bulletin. 32(3): 127-136.

Mortimore, M. 2002. "When does apparel become a peril? On the nature of industrialization in the Caribbean Basin", in Gereffi, G., Spener, D. and Bair, J. (eds.), Free trade and uneven development: The North American apparel industry after NAFTA. Philadelphia, Temple University Press.

Nadvi, K. and Wältring, F. 2002. Making sense of global standards. INEF Report 58. Duisburg, Institut für Entwicklung und Frieden, Gerhard-Mercator University.

Navas-Alemán, L. and Bazan, L. 2003. Local implementation of quality, labour and environmental standards: Opportunities for upgrading in the footwear industry. SEED Working Paper No. 45. Geneva, ILO.

Quadros, R. 2002. Global quality standards, chain governance and the technological upgrading of Brazilian auto-components producers. IDS Working Paper 156. Brighton, Institute of Development Studies.

Quadros, R., Queiroz, S., Humphrey, J., Consoni, F., Costa, I. and Fonseca, R.R. 2000. Globalização e reestruturação da cadeia produtiva na indústria automotiva: Qual è o papel do Mercosul? Final Report to IPEA. Campinas, Departamento de Política Científica e Tecnológica.

Sadler, D. 1999. "Internationalization and specialization in the European automotive components sector: Implications for the hollowing-out thesis", in Regional Studies. 33(2), April: 109-119.

Schmitz, H. 1995. "Small shoemakers and Fordist giants: Tale of a supercluster", in World Development. 23(1): 9-28.

----. 1999. "Global competition and local cooperation: Success and failure in the Sinos Valley, Brazil", in World Development. 27(9): 1627-1650.

----. (ed.). 2004. Local enterprises in the global economy: Issues of governance and upgrading. Cheltenham, Edward Elgar.

Schmitz, H. and Knorringa, P. 1999. Learning from global buyers. IDS Working Paper 100. Brighton, Institute of Development Studies.

Sturgeon, T. 2002. "Modular production networks: A new American model of industrial organization", in Industrial and Corporate Change. 11(3): 451-495. 
Sturgeon, T. and Florida, R. 1999. The world that changed the machine: Globalization and jobs in the automotive industry. Final Report to the Alfred P. Sloan Foundation. Cambridge MA, MIT.

Sturgeon, T. and Lee, J.-R. 2001. Industry co-evolution and the rise of a shared supply-base for electronics manufacturing. Paper presented at the Nelson and Winter Conference, Aalborg, June

Sturgeon, T. and Lester, R. 2001. Upgrading East Asian industries: New challenges for local suppliers. Report Prepared for the World Bank Project on East Asia's Economic Future. Cambridge MA, Industrial Performance Centre, MIT.

Tewari, M. 1999. "Successful adjustment in Indian industry: The case of Ludhiana's woolen knitwear cluster", in World Development. 27(9): 1651-1672.

Tewari, M. and Pillai, P. (forthcoming). Negotiated collective action and adjustment in a labor intensive industry: The case of Tamil Nadu's Leather Industry. Oxford Development Studies.

UNCTAD. 2002a. Export diversification, market access and competitiveness. Doc. TD/B/Com.1/54. Trade and Development Board, Commission on Trade in Goods, Services and Commodities. Geneva.

----. 2002b. Trade and Development Report, 2002. New York and Geneva.

----. 2003. The African Growth and Opportunity Act: A preliminary assessment. Doc. UNCTAD/ITCD/TSB/2003/1. New York and Geneva. (Available at http://www.unctad.org/en/docs//itcdtsb20031_en.pdf - visited on 15 January 2004).

UNIDO. 2002. Industrial Development Report 2002/2003: Competing through innovation and learning. Vienna.

United States International Trade Commission. 2002. U.S. trade and investment with sub-Saharan Africa: Third annual report. USITC Publication 3552. Washington DC. (Available at http://www.usitc.gov/africa/pub3552.pdf - visited on 10 January 2004).

Wortzel, L. and Wortzel, H. 1981. "Export marketing strategies for NIC and LDC-based firms", in Columbia Journal of World Business.16(1): 51-60. 


\section{Policy Integration Department Working Papers prepared for the World Commission on the Social Dimension of Globalization}

No. 16 International finance: Meeting the needs of people in developing countries, José Guilherme Almeida dos Reis

No. 17 The gender dimensions of the globalization of production, Stephanie Barrientos, Naila Kabeer and Naomi Hossain

No. 18 Social exclusion in the context of globalization, Jan Breman

No. 19 Gender and globalization: A macroeconomic perspective, Çağatay Nilüfer and Ertük Korkurt

No. 20 Globalization, social exclusion, and work: with special reference to informal employment and gender, Marilyn Carr and Martha Chen

No. 21 Resources for social development, Anthony Clunies Ross

No. 22 Does the new international trade regime leave room for industrialization policies in the middle-income countries?, Alisa DiCaprio and Alice Amsden

No. 23 Social dimension of globalization in Latin America: Lessons from Bolivia and Chile, Alvaro García Hurtado

No. 24 Globalization: Social impact and policy actions: A partly annotated bibliography, Bernhard Gunter and Rolph van der Hoeven

No. 25 The social dimension of global production systems, Susan Hayter

No. 26 Reforming global economic and social governance:

a critical review of recent programmatic thinking, Jeremy Heimans

No. 27 Corporate social responsibility: An issues paper, Michael Hopkins

No. 28 Upgrading in global value chains, John Humphrey

No. 29 Implications of globalization and economic restructuring for skills development in Sub-Sahara Africa, Richard K. Johanson

No. 30 The outcome and impact of the main international commissions on development issues, Frédéric Lapeyre

No. 31 Globalization and structural adjustment as a development tool, Frédéric Lapeyre

No. 32 Globalization and perceptions of social inequality, Malte Luebker

No. 33 The changing structure of trade linked to global production systems:

What are the policy implications?, William Milberg

No. 34 Corporate social responsibility: An overview of principles and practice, Jill Murray

No. 35 Inclusive development strategy in an era of globalization, Ignacy Sachs

No. 36 Social consequences of the globalization of the media and communications sector: Some strategic considerations, Seán Ó. Siochrú

No. 37 Globalization, history and international migration - A view from Latin America, Andrés Solimano

No. 38 Towards a different kind of globalization, or how the anti-globalizers view the world, Gijsbert van Liemt 